Argonne

ANL/EVS/AGEM/TR-08-04

\title{
November 2007 Monitoring Results for Barnes, Kansas
}

\author{
Environmental Science Division
}




\begin{abstract}
About Argonne National Laboratory
Argonne is a U.S. Department of Energy laboratory managed by UChicago Argonne, LLC under contract DE-AC02-06CH11357. The Laboratory's main facility is outside Chicago, at 9700 South Cass Avenue, Argonne, Illinois 60439. For information about Argonne, see www.anl.gov.
\end{abstract}

\title{
Availability of This Report
}

This report is available, at no cost, at http://www.osti.gov/bridge. It is also available on paper to the U.S. Department of Energy and its contractors, for a processing fee, from:

U.S. Department of Energy

Office of Scientific and Technical Information

P.O. Box 62

Oak Ridge, TN 37831-0062

phone (865) 576-8401

fax (865) 576-5728

reports@adonis.osti.gov

\section{Disclaimer}

This report was prepared as an account of work sponsored by an agency of the United States Government. Reference herein to any specific commercial product, process, or service by trade name, trademark, manufacturer, or otherwise, does not necessarily constitute or imply its endorsement, recommendation, or favoring by the United States Government or any agency thereof. The views and opinions of document authors expressed herein do not necessarily state or reflect those of the United States Government or any agency thereof, Argonne National Laboratory, or UChicago Argonne, LLC. 


\section{November 2007 Monitoring Results for Barnes, Kansas}

by

Applied Geosciences and Environmental Management Section

Environmental Science Division, Argonne National Laboratory

February 2008

USDA 


\section{Contents}

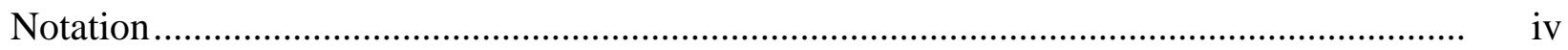

1 Introduction and Background............................................................................... 1-1

2 Sampling and Analysis Activities .............................................................................. 2-1

2.1 Measurement of Groundwater Levels .............................................................. 2-1

2.2 Monitoring Well Sampling and Analyses .......................................................... 2- 2-1

2.3 Handling and Disposal of Investigation-Derived Waste.......................................... 2-2

2.4 Quality Control for Sample Collection, Handling, and Analysis............................ 2-2

3 Results and Discussion........................................................................................ 3-1

3.1 Groundwater Level Data ................................................................................ 3-1

3.2 Analytical Results for Volatile Organic Compounds in Groundwater Samples....... 3-2

4 Conclusions and Recommendations............................................................................ 4- 4-1

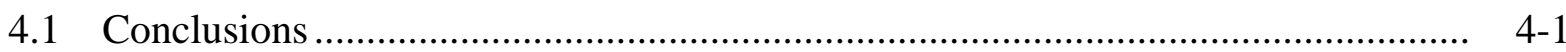

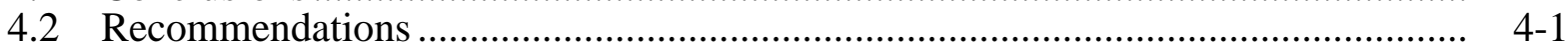

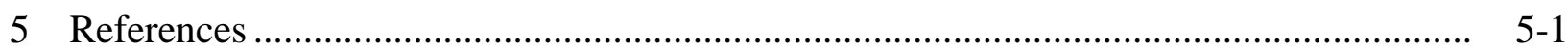

Appendix A: Sampling Activities and Field Measurements at Barnes in November 2007 .................................................................................. A-1

Appendix B: Sample Documentation from Envirosystems, Inc.......................................... B-1

Appendix C: Analytical Results from the AGEM Laboratory for Dual Analyses of Samples Collected at Barnes in November 2007

C-1

\section{Tables}

3.1 Hand-measured water levels at Barnes, May 2007 to December 2007 ...................... 3-3

3.2 Analytical results from the AGEM Laboratory for volatile organic compounds in groundwater samples collected at Barnes, July 2006 to November 2007. 
A.1 Sequence of sampling activities during the November 2007 monitoring event at Barnes, Kansas

A.2 Field measurements for groundwater samples collected at Barnes, July 2006 to November 2007

C.1 Analytical Results from the AGEM Laboratory for Samples and Replicate Collected at Barnes in November 2007

\section{Figures}

1.1 Groundwater sampling locations at Barnes as of November 2007

2.1 Wells at Barnes equipped with data loggers for water level monitoring, as of November 2007

3.1 Hydrographs summarizing monthly results of long-term water level monitoring in wells at Barnes, May 2007 to December 2007

3.2 Analytical results for carbon tetrachloride in groundwater samples collected at Barnes in November 2007.

3.3 Analytical results for carbon tetrachloride in groundwater samples collected at Barnes in November 2007 and April 2007. 


\section{Notation}

AGEM Applied Geosciences and Environmental Management

AMSL above mean sea level

BGL below ground level

${ }^{\circ} \mathrm{C} \quad$ degree(s) Celsius

CCC Commodity Credit Corporation

COC chain of custody

EPA U.S. Environmental Protection Agency

$\mathrm{ft} \quad$ foot (feet)

gal gallon(s)

KDHE Kansas Department of Health and Environment

$\mu \mathrm{g} / \mathrm{L} \quad$ microgram(s) per liter

$\mu \mathrm{S} / \mathrm{cm} \quad$ microsiemen(s) per centimeter

$\min \quad$ minute

TOC top of casing

USDA U.S. Department of Agriculture

VOC volatile organic compound 


\section{November 2007 Monitoring Results for Barnes, Kansas}

\section{Introduction and Background}

The Commodity Credit Corporation of the U.S. Department of Agriculture (CCC/USDA) formerly operated a grain storage facility (during most of the interval 1949-1974) at Barnes, Kansas. Carbon tetrachloride contamination was initially detected in 1986 in the town's public water supply wells. In 2006-2007, the CCC/USDA conducted a comprehensive targeted investigation at and near its former property in Barnes to investigate this contamination.

In November 2007, the CCC/USDA began quarterly groundwater monitoring at Barnes. The monitoring is being conducted on behalf of the CCC/USDA by Argonne National Laboratory, in accord with the recommendations made in the report for the 2006-2007 targeted investigation (Argonne 2007). The objective is to monitor the carbon tetrachloride contamination identified in the groundwater at Barnes. The sampling is presently conducted in a network of 28 individual monitoring wells at 19 distinct locations, 2 public water supply wells, and 1 private well (Figure 1.1).

The results of the 2006-2007 targeted investigation demonstrated the presence of carbon tetrachloride contamination at levels slightly exceeding the Kansas Department of Health and Environment (KDHE) Tier 2 risk-based screening level of $5.0 \mu \mathrm{g} / \mathrm{L}$ for this compound, in a plume that appears to extend from the former CCC/USDA property northwestward, toward the Barnes public water supply wells. Information obtained during the 2006-2007 investigation indicates that at least one other potential source might have contributed to the groundwater contaminant plume (Argonne 2007). The present report presents the results of the November 2007 sampling event that followed the targeted investigation. 


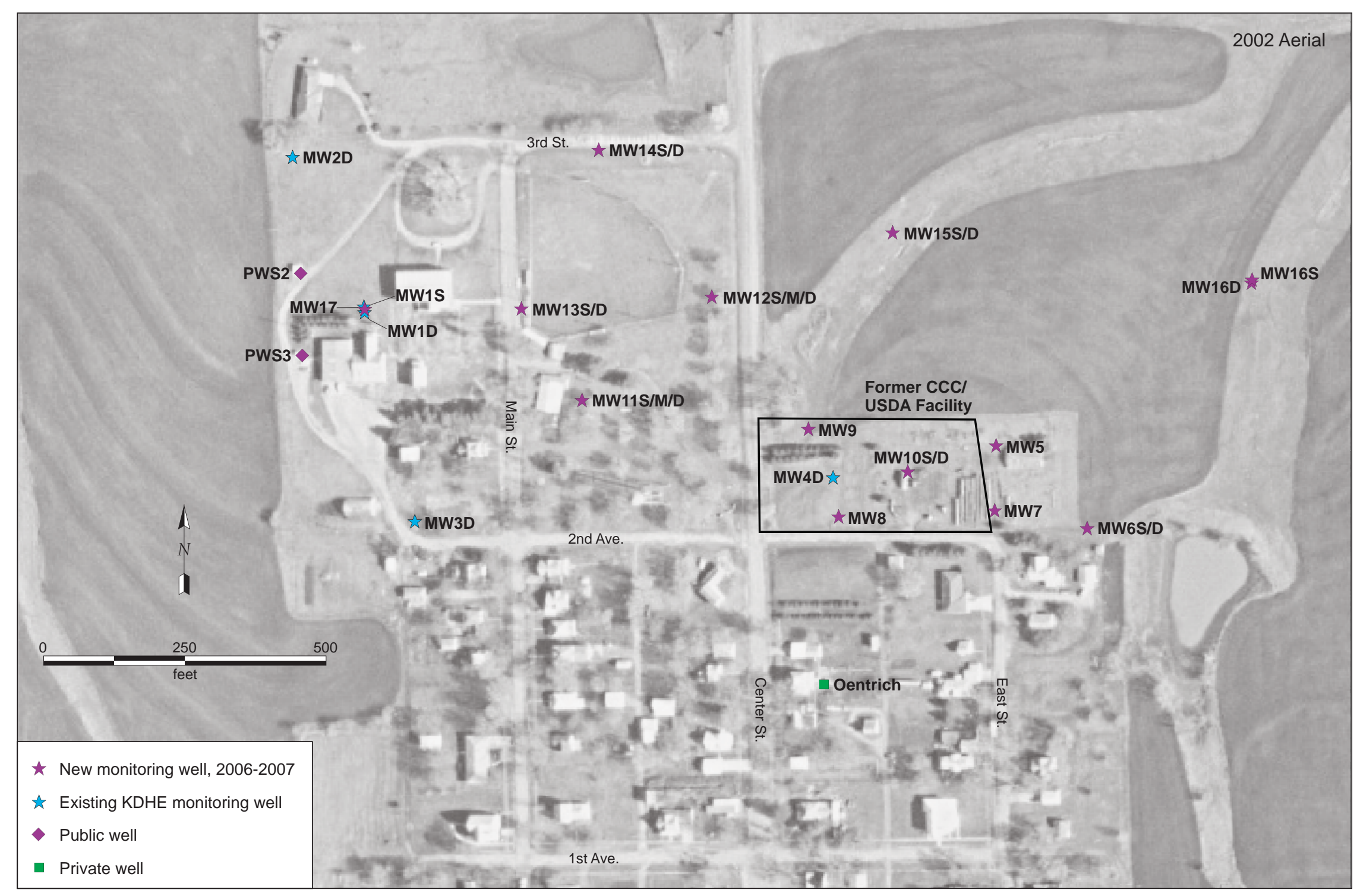

FIGURE 1.1 Groundwater sampling locations at Barnes, as of November 2007. 


\section{Sampling and Analysis Activities}

\subsection{Measurement of Groundwater Levels}

In conjunction with the groundwater sampling event reported here, groundwater levels were measured manually on November 18-19, 2007, in 28 monitoring wells (MW1S, MW1D, MW2D, MW3D, MW4D, MW5, MW6S, MW6D, MW7, MW8, MW9, MW10S, MW10D, MW11S, MW11M, MW11D, MW12S, MW12M, MW12D, MW13S, MW13D, MW14S, MW14D, MW15S, MW15D, MW16S, MW16D, MW17). Before these wells were purged in preparation for sampling, a water level indicator was used to measure the depth to groundwater and the total depth of each well, to within $0.01 \mathrm{ft}$, from the top of the well casing. Monitoring wells MW1S and MW12S were measured but were found to be dry and consequently could not be sampled. Two public water supply wells (PWS2 and PWS3) and 1 private well (Oentrich) were sampled but not measured. All of the well locations are shown in Figure 1.1.

During the present monitoring period, another set of manual measurements of water levels was made in all available wells on June 9, 2007.

In addition to the manual water level measurements, data recorders have been gathering long-term data on the groundwater elevation and gradient at monitoring wells MW1D, MW2D, MW3D, MW4D, MW7, MW9, MW14D, MW15D, and MW16D and at the Oentrich private well (Figure 2.1). The data loggers record water levels continuously at 30-min intervals. Additional sets of manual water level measurements were made in these wells equipped with data loggers on September 7, 2007, and December 19, 2007.

The groundwater level data are presented and discussed in Section 3.1.

\subsection{Monitoring Well Sampling and Analyses}

After measurement of water levels on November 18-19, 2007, and before sampling, the wells were purged of a minimum three well volumes or until they were dry. Field measurements of temperature, $\mathrm{pH}$, and conductivity were taken during purging until the measurements stabilized. All sampling and field analyses were performed in accord with procedures in the Master Work Plan (Argonne 2002). The sequence of activities during the November well 
sampling event is summarized in Appendix A, Table A.1. The field measurements are in Appendix A, Table A.2.

Groundwater samples designated for analyses for volatile organic compounds (VOCs) were collected in appropriate laboratory containers, labeled, packaged, and chilled to $4^{\circ} \mathrm{C}$ by placement in ice-filled coolers. The samples were shipped via an overnight delivery service to the Applied Geosciences and Environmental Management (AGEM) Laboratory at Argonne for VOCs analyses with U.S. Environmental Protection Agency (EPA) Method 524.2 (EPA 1995). Aliquots of selected samples (chosen in the field) were also shipped to Envirosystems, Inc., Columbia, Maryland, for verification VOCs analyses according to EPA Contract Laboratory Program protocols.

The analytical results are presented and discussed in Section 3.2.

\subsection{Handling and Disposal of Investigation-Derived Waste}

Purge water generated as potentially contaminated investigation-derived waste was containerized on-site in 55-gal drums. The accumulated purge water was sampled and analyzed for VOCs (including ethylene dibromide) and was found to contain no detectable concentration of either carbon tetrachloride or chloroform. Nitrate was present at $2.8 \mathrm{mg} / \mathrm{L}$. The water was disposed of at the Sabetha, Kansas, publicly owned treatment works on December 14, 2007 (Sabetha 2007).

\subsection{Quality Control for Sample Collection, Handling, and Analysis}

Quality assurance/quality control procedures followed during the November 2007 monitoring event are described in detail in the Master Work Plan (Argonne 2002). The results are summarized as follows:

- Sample collection and handling activities were monitored by the documentation of samples as they were collected and the use of chain-ofcustody forms and custody seals to ensure sample integrity during handling and shipment. 
- Samples designated for VOCs analyses were received with custody seals intact and at the appropriate preservation temperature. All samples sent to the AGEM Laboratory were analyzed within the required holding times.

- Quality control samples collected to monitor sample-handling activities (trip blanks) and method blanks analyzed with the samples to monitor analytical methodologies were all free of carbon tetrachloride and chloroform contamination.

- Groundwater samples were analyzed for VOCs at the AGEM Laboratory with the purge-and-trap method on a gas chromatograph-mass spectrometer system. Calibration checks analyzed with each sample delivery group were required to be within $\pm 20 \%$ of the standard. Surrogate standard determinations performed on samples and blanks were within the specified range of $80-120 \%$ for all samples, in either the initial analysis or a successful reanalysis.

- In accordance with the procedures defined in the Master Work Plan (Argonne 2002), three groundwater samples were submitted to a second laboratory (Envirosystems) for verification analysis according to the protocols of the EPA's Contract Laboratory Program. The Envirosystems laboratory failed to analyze the samples. Documentation is in Appendix B.

- Results from the AGEM Laboratory for dual analyses of the groundwater samples are in Appendix C, Table C.1. The results of the dual analyses compare well, indicating consistency in the sampling and analytical methodologies. 


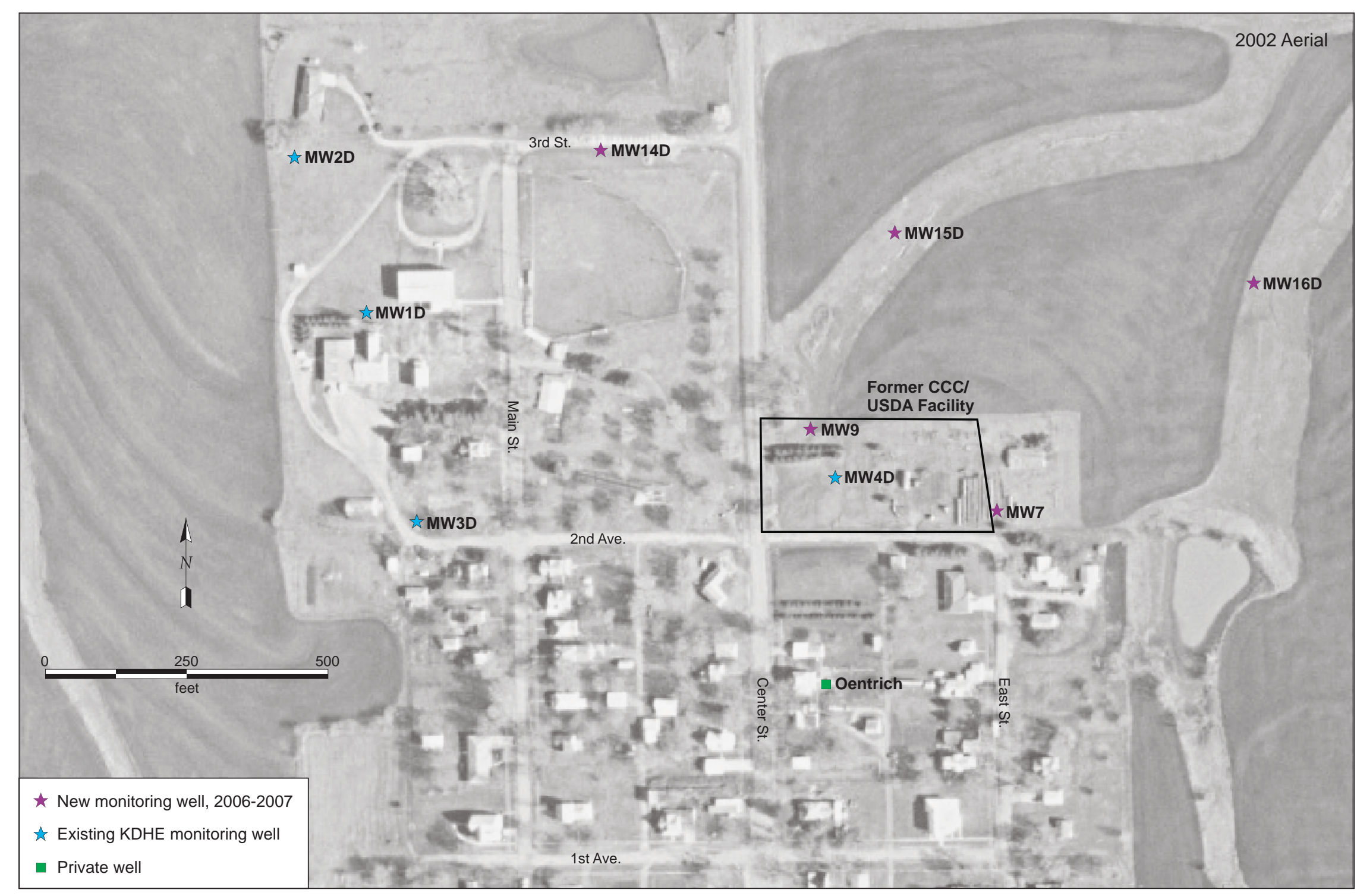

FIGURE 2.1 Wells at Barnes equipped with data loggers for water level monitoring, as of November 2007. 


\section{Results and Discussion}

\subsection{Groundwater Level Data}

The results of manual water level measurements in May-December 2007 are in Table 3.1. The tables for Section 3 are grouped at the end of the section's text, before the figures.

The potentiometric surface at Barnes is depicted extensively in the targeted investigation report (Figure 4.7 in Argonne 2007). The recent results (Table 3.1) are consistent with the previous measurements, indicating an apparent groundwater flow direction toward the northwest, toward the public water supply wells. The results of the 2006-2007 targeted investigation (Argonne 2007) indicated that operation of the public water supply wells strongly influences the groundwater flow direction.

The hydrographs in Figure 3.1 summarize data for the period May 1, 2007, through December 19, 2007, from the recording transducers installed for long-term water level monitoring in wells MW1D, MW2D, MW3D, MW4D, MW7, MW9, MW14D, MW15D, MW16D, and the Oentrich well. (The well locations are shown in Figure 2.1.) The patterns in Figure 3.1 are similar to previous data (Figure 4.6 in Argonne 2007). The hydrographs show responses to pumping of the public water supply wells that are characterized by drawdowns of as much as $2 \mathrm{ft}$ during pumping, with almost immediate rebound when pumping stops. The most prominent drawdowns are consistently observed in wells MW1D and MW2D, which are the closest monitoring points to the public wells. The hydrographs indicate an overall rise in water levels in June and July 2007, followed by a decline in subsequent months.

After the transducer in well MW15D was installed on May 1, 2007, it recorded responses consistent with those for the other monitoring wells until September 7, 2007. At that time, its responses became erratic and no longer correlated with those for the other wells. Consequently, the data for well MW15D recorded after September 7, 2007, are considered suspect and are not shown in Figure 3.1. The recorder will be reprogrammed or replaced. 


\subsection{Analytical Results for Volatile Organic Compounds in Groundwater Samples}

The analytical data for VOCs in the groundwater samples collected in November 2007 are in Table 3.2, together with data for the previous sampling events conducted at Barnes. The lateral distribution of carbon tetrachloride in groundwater in the November 2007 sampling event is illustrated in Figure 3.2. The overall pattern is similar to that observed in the 2006-2007 targeted investigation (Figure 3.3 [results for April 2007 and November 2007]).

Carbon tetrachloride was detected in November 2007 in 19 of the 29 groundwater samples collected (at 13 of the 19) distinct monitoring locations; Figure 3.2 and Table 3.2). Carbon tetrachloride concentrations ranged from $0.3 \mathrm{~J} \mu \mathrm{g} / \mathrm{L}$ (at $\mathrm{MW6S}$ ) to a maximum of $23 \mu \mathrm{g} / \mathrm{L}$ (at MW8). The concentrations of carbon tetrachloride in 8 of the 29 groundwater samples were above the regulatory level of $5.0 \mu \mathrm{g} / \mathrm{L}$.

Chloroform concentrations ranging from $0.2 \mathrm{~J} \mu \mathrm{g} / \mathrm{L}$ (at MW13D) to $5.1 \mu \mathrm{g} / \mathrm{L}$ (at MW12M) were detected in 10 of the 29 groundwater samples (at 8 of the 19) distinct sampling locations; Table 3.2). Chloroform occurred in association with the more elevated carbon tetrachloride levels identified at MW4D, MW8, MW9, MW10S, MW10D, MW12M, MW13S, MW13D, and MW15S.

The present results indicate that carbon tetrachloride levels measured in November 2007 at sampling locations on the former CCC/USDA property had declined (MW4D, MW10S) or risen slightly (MW8, MW9, MW10D) since the previous sampling event. Outside the former CCC/USDA property, the carbon tetrachloride concentrations declined (MW1D, MW11D, MW12M, MW13S, MW14D), increased slightly (MW6D, MW7, MW11M, MW12D, MW13D, MW14S, MW15S, Oentrich), or remained unchanged (MW2D, MW3D, MW5, MW11S, MW15D, MW16S, MW16D, MW17).

The lateral distribution of the contaminant in groundwater was similar to the distribution observed previously (Figure 4.9 in Argonne 2007). From April 2007 to November 2007, the carbon tetrachloride concentration detected in sentinel well MW15S increased from $1.5 \mu \mathrm{g} / \mathrm{L}$ to $8.7 \mu \mathrm{g} / \mathrm{L}$. In the other sentinel wells (as defined in Section 5.1 of Argonne 2007), the carbon tetrachloride decreased (MW14D), remained the same (MW15D, MW16S, MW17), or increased by $0.5 \mu \mathrm{g} / \mathrm{L}$ or less (MW6D, MW14S). A trace level of carbon tetrachloride was detected in monitoring well MW6S, which was dry and could not be sampled in April 2007. 
TABLE 3.1 Hand-measured water levels at Barnes, May 2007 to December 2007.

\begin{tabular}{|c|c|c|c|c|c|c|c|c|c|c|c|}
\hline \multirow[b]{3}{*}{ Well } & \multirow{3}{*}{$\begin{array}{l}\text { Reference } \\
\text { Elevation } \\
\text { (ft AMSL) }\end{array}$} & \multicolumn{10}{|c|}{ Water Level Depth (feet below top of casing) on Date Indicated } \\
\hline & & \multicolumn{2}{|c|}{$5 / 10 / 07$} & \multicolumn{2}{|c|}{$6 / 9 / 07$} & \multicolumn{2}{|c|}{$9 / 7 / 07$} & \multicolumn{2}{|c|}{$11 / 18 / 07-11 / 19 / 07$} & \multicolumn{2}{|c|}{$12 / 19 / 07$} \\
\hline & & Time & Depth & Time & Depth & Time & Depth & Day, Time & Depth & Time & Depth \\
\hline MW1S & 1351.58 & & & $11: 48$ & Dry & & & $11 / 18,16: 45$ & Dry & & \\
\hline MW1D & 1351.33 & $14: 03$ & 130.63 & $11: 42$ & 129.72 & $11: 31$ & 123.81 & $11 / 18,16: 40$ & 124.89 & $10: 53$ & 125.54 \\
\hline MW2D & 1348.85 & $14: 45$ & 128.32 & $12: 01$ & 127.57 & $11: 12$ & 121.56 & $11 / 18,17: 10$ & 122.56 & $11: 42$ & 123.20 \\
\hline MW3D & 1345.99 & 13:31 & 125.03 & $11: 34$ & 123.29 & $11: 43$ & 118.27 & 11/19,09:00 & 126.25 & $10: 13$ & 120.09 \\
\hline MW4D & 1326.32 & $16: 30$ & 105.33 & $10: 01$ & 103.30 & 9:04 & 99.86 & $11 / 19,08: 55$ & 101.39 & $14: 56$ & 100.54 \\
\hline MW5 & 1327.20 & & & $09: 40$ & 104.69 & & & $11 / 19,09: 15$ & 102.78 & & \\
\hline MW6S & 1323.13 & & & 09:04 & 96.03 & & & $11 / 19,09: 30$ & 96.10 & & \\
\hline MW6D & 1323.15 & & & 09:05 & 100.35 & & & $11 / 19,09: 35$ & 98.50 & & \\
\hline MW7 & 1329.91 & $16: 06$ & 109.24 & $09: 35$ & 107.15 & $9: 20$ & 103.63 & $11 / 19,13: 10$ & 105.50 & $14: 35$ & 104.48 \\
\hline MW8 & 1330.06 & & & $10: 08$ & 107.02 & & & $11 / 19,10: 40$ & 105.17 & & \\
\hline MW9 & 1321.86 & $15: 08$ & 101.04 & $10: 33$ & 99.01 & $10: 42$ & 94.95 & $11 / 19,13: 05$ & 97.20 & $13: 17$ & 96.25 \\
\hline Oentrich ${ }^{a}$ & 1336.93 & $16: 59$ & 115.70 & $10: 14$ & 113.74 & $12: 15$ & 109.74 & $11 / 19,12: 10$ & $\mathrm{NM}^{\mathrm{b}}$ & $15: 27$ & 116.55 \\
\hline MW10S & 1331.33 & & & $09: 48$ & 77.20 & & & $11 / 19,15: 00$ & 77.81 & & \\
\hline MW10D & 1331.33 & & & 09:50 & 108.61 & & & $11 / 19,15: 05$ & 106.22 & & \\
\hline MW11S & 1336.58 & & & $11: 19$ & 22.95 & & & $11 / 19,11: 30$ & 29.20 & & \\
\hline MW11M & 1336.51 & & & $11: 21$ & 84.91 & & & $11 / 19,11: 35$ & 82.33 & & \\
\hline MW11D & 1336.53 & & & $11: 23$ & 113.76 & & & $11 / 19,12: 00$ & 112.46 & & \\
\hline MW12S & 1327.46 & & & $10: 43$ & 51.73 & & & $11 / 18,13: 15$ & Dry & & \\
\hline MW12M & 1327.46 & & & $10: 41$ & 75.92 & & & $11 / 19,14: 10$ & 74.50 & & \\
\hline MW12D & 1327.52 & & & $10: 45$ & 105.62 & & & $11 / 18,13: 30$ & 102.00 & & \\
\hline MW13S & 1342.36 & & & $11: 13$ & 94.70 & & & $11 / 19,14: 00$ & 92.23 & & \\
\hline MW13D & 1342.37 & & & $11: 08$ & 119.73 & & & $11 / 19,12: 50$ & 117.83 & & \\
\hline MW14S & 1332.69 & & & $10: 59$ & 111.28 & & & $11 / 18,14: 55$ & 106.75 & & \\
\hline MW14D & 1332.74 & $14: 55$ & 112.33 & $10: 55$ & 111.20 & $10: 56$ & 105.81 & $11 / 18,15: 38$ & 107.10 & $12: 07$ & 107.23 \\
\hline MW15S & 1309.34 & & & $10: 28$ & 87.39 & & & $11 / 18,17: 37$ & 84.33 & & \\
\hline MW15D & 1309.29 & $15: 34$ & 84.40 & $10: 24$ & 80.72 & $10: 19$ & 77.87 & $11 / 18,16: 00$ & 70.20 & $12: 56$ & 80.84 \\
\hline MW16S & 1299.47 & & & 09:18 & 77.22 & & & $11 / 19,09: 40$ & 75.30 & & \\
\hline MW16D & 1299.52 & $15: 54$ & 77.63 & 09:20 & 75.74 & $10: 02$ & 73.67 & $11 / 19,09: 45$ & 74.50 & $14: 53$ & 74.62 \\
\hline MW17 & 1351.77 & & & $11: 50$ & 104.62 & & & $11 / 19,08: 02$ & 102.68 & & \\
\hline
\end{tabular}

a The Oentrich well water level is measured from the concrete at the top of the well vault. The values shown have been corrected by $5.5 \mathrm{ft}$ to give the measured depth from the top of the casing.

b NM, not measured. No access to wellhead. 
TABLE 3.2 Analytical results from the AGEM Laboratory for volatile organic compounds in groundwater samples collected at Barnes, July 2006 to November 2007.

\begin{tabular}{|c|c|c|c|c|c|c|}
\hline \multirow[b]{2}{*}{ Well } & \multirow[b]{2}{*}{$\begin{array}{l}\text { Screen Interval } \\
\quad(\mathrm{ft} B G L)\end{array}$} & \multirow[b]{2}{*}{ Sample } & \multirow[b]{2}{*}{$\begin{array}{l}\text { Sample } \\
\text { Date }\end{array}$} & \multicolumn{3}{|c|}{ Concentration $(\mu \mathrm{g} / \mathrm{L})$} \\
\hline & & & & $\begin{array}{c}\text { Carbon } \\
\text { Tetrachloride }\end{array}$ & Chloroform & $\begin{array}{l}\text { Methylene } \\
\text { Chloride }\end{array}$ \\
\hline \multicolumn{7}{|c|}{ Existing KDHE monitoring wells } \\
\hline MW1S & 13.3-23.3 & $\begin{array}{l}\text { Not sampled (well dry) } \\
\text { Not sampled (well dry) } \\
\text { Not sampled (well dry) }\end{array}$ & $\begin{array}{r}7 / 19 / 06 \\
4 / 4 / 07 \\
11 / 18 / 07\end{array}$ & $\begin{array}{l}- \\
- \\
-\end{array}$ & $\begin{array}{l}- \\
- \\
-\end{array}$ & $\begin{array}{l}- \\
- \\
-\end{array}$ \\
\hline MW1D & $139.85-159.4$ & $\begin{array}{l}\text { BAMW1D-W-21688 } \\
\text { BAMW1D-W-22565 } \\
\text { BAMW1D-W-22593 }\end{array}$ & $\begin{array}{r}7 / 19 / 06 \\
4 / 4 / 07 \\
11 / 18 / 07\end{array}$ & $\begin{array}{r}1.0 \\
1.2 \\
\text { ND }\end{array}$ & $\begin{array}{l}\mathrm{ND}^{\mathrm{a}} \\
\mathrm{ND} \\
\mathrm{ND}\end{array}$ & $\begin{array}{l}\text { ND } \\
\text { ND } \\
\text { ND }\end{array}$ \\
\hline MW2D & 133.26-152-93 & $\begin{array}{l}\text { BAMW2D-W-21687 } \\
\text { BAMW2D-W-22564 } \\
\text { BAMW2D-W-22594 }\end{array}$ & $\begin{array}{r}7 / 19 / 06 \\
4 / 4 / 07 \\
11 / 18 / 07\end{array}$ & $\begin{array}{l}\text { ND } \\
\text { ND } \\
\text { ND }\end{array}$ & $\begin{array}{l}\text { ND } \\
\text { ND } \\
\text { ND }\end{array}$ & $\begin{array}{l}\text { ND } \\
\text { ND } \\
\text { ND }\end{array}$ \\
\hline MW3D & $133.02-152.73$ & $\begin{array}{l}\text { BAMW3D-W-21686 } \\
\text { BAMW3D-W-22567 } \\
\text { BAMW3D-W-22595 }\end{array}$ & $\begin{array}{r}7 / 19 / 06 \\
4 / 4 / 07 \\
11 / 19 / 07\end{array}$ & $\begin{array}{l}\text { ND } \\
\text { ND } \\
\text { ND }\end{array}$ & $\begin{array}{l}\text { ND } \\
\text { ND } \\
\text { ND }\end{array}$ & $\begin{array}{l}\text { ND } \\
\text { ND } \\
\text { ND }\end{array}$ \\
\hline MW4D & $98.38-118.22$ & $\begin{array}{l}\text { BAMW4D-W-21690 } \\
\text { BAMW4D-W-22583 } \\
\text { BAMW4D-W-22596 }\end{array}$ & $\begin{array}{r}7 / 20 / 06 \\
4 / 6 / 07 \\
11 / 19 / 07\end{array}$ & $\begin{array}{l}2.1 \\
3.5 \\
1.7\end{array}$ & $\begin{array}{l}\text { ND } \\
0.1 \mathrm{~J}^{\mathrm{b}} \\
0.4 \mathrm{~J}\end{array}$ & $\begin{array}{l}\text { ND } \\
\text { ND } \\
\text { ND }\end{array}$ \\
\hline CCC/US & wells installed $d$ & ng the 2006-2007 invest & & & & \\
\hline MW5 & $110-120$ & $\begin{array}{l}\text { BAMW5-W-22589 } \\
\text { BAMW5-W-22597 }\end{array}$ & $\begin{array}{r}4 / 6 / 07 \\
11 / 19 / 07\end{array}$ & $\begin{array}{l}0.6 \mathrm{~J} \\
0.6 \mathrm{~J}\end{array}$ & $\begin{array}{l}\text { ND } \\
\text { ND }\end{array}$ & $\begin{array}{l}\text { ND } \\
\text { ND }\end{array}$ \\
\hline MW6S & $90.5-100.5$ & $\begin{array}{l}\text { Not sampled (well dry) } \\
\text { BAMW6S-W-22598 }\end{array}$ & $\begin{array}{r}4 / 4 / 07 \\
11 / 19 / 07\end{array}$ & $\overline{0} .3 \mathrm{~J}$ & ND & $\overline{\mathrm{ND}}$ \\
\hline MW6D & $105-115$ & $\begin{array}{l}\text { BAMW6D-W-22573 } \\
\text { BAMW6D-W-22599 }\end{array}$ & $\begin{array}{r}4 / 5 / 07 \\
11 / 19 / 07\end{array}$ & $\begin{array}{l}\text { ND } \\
0.5 \mathrm{~J}\end{array}$ & $\begin{array}{l}\text { ND } \\
\text { ND }\end{array}$ & $\begin{array}{l}\text { ND } \\
\text { ND }\end{array}$ \\
\hline MW7 & $116-126$ & $\begin{array}{l}\text { BAMW7-W-22588 } \\
\text { BAMW7-W-22600 }\end{array}$ & $\begin{array}{r}4 / 6 / 07 \\
11 / 19 / 07\end{array}$ & $\begin{array}{l}1.0 \\
2.6\end{array}$ & $\begin{array}{l}\text { ND } \\
\text { ND }\end{array}$ & $\begin{array}{l}\text { ND } \\
\text { ND }\end{array}$ \\
\hline MW8 & $110-120$ & $\begin{array}{l}\text { BAMW8-W-22584 } \\
\text { BAMW8-W-22601 }\end{array}$ & $\begin{array}{r}4 / 6 / 07 \\
11 / 19 / 07\end{array}$ & $\begin{array}{l}14 \\
23\end{array}$ & $\begin{array}{l}0.7 \mathrm{~J} \\
0.6 \mathrm{~J}\end{array}$ & $\begin{array}{l}\text { ND } \\
\text { ND }\end{array}$ \\
\hline MW9 & $100-110$ & $\begin{array}{l}\text { BAMW9-W-22582 } \\
\text { BAMW9-W-22602 }\end{array}$ & $\begin{array}{r}4 / 5 / 07 \\
11 / 19 / 07\end{array}$ & $\begin{array}{l}1.0 \\
7.7\end{array}$ & $\begin{array}{l}\text { ND } \\
0.6 \mathrm{~J}\end{array}$ & $\begin{array}{l}\text { ND } \\
\text { ND }\end{array}$ \\
\hline MW10S & $93-103$ & $\begin{array}{l}\text { BAMW10S-W-22586 } \\
\text { BAMW10S-W-22603 }\end{array}$ & $\begin{array}{r}4 / 6 / 07 \\
11 / 19 / 07\end{array}$ & $\begin{array}{l}20 \\
11\end{array}$ & $\begin{array}{l}1.4 \\
0.7 \mathrm{~J}\end{array}$ & $\begin{array}{l}\text { ND } \\
\text { ND }\end{array}$ \\
\hline MW10D & $115-125$ & $\begin{array}{l}\text { BAMW10D-W-22585 } \\
\text { BAMW10D-W-22604 }\end{array}$ & $\begin{array}{r}4 / 6 / 07 \\
11 / 19 / 07\end{array}$ & $\begin{array}{l}2.4 \\
6.3\end{array}$ & $\begin{array}{l}0.2 \mathrm{~J} \\
0.5 \mathrm{~J}\end{array}$ & $\begin{array}{l}\text { ND } \\
\text { ND }\end{array}$ \\
\hline MW11S & $40-50$ & $\begin{array}{l}\text { BAMW11S-W-22570 } \\
\text { BAMW11S-W-22605 }\end{array}$ & $\begin{array}{r}4 / 4 / 07 \\
11 / 19 / 07\end{array}$ & $\begin{array}{l}\text { ND } \\
\text { ND }\end{array}$ & $\begin{array}{l}1.1 \\
0.6 \mathrm{~J}\end{array}$ & $\begin{array}{l}\text { ND } \\
\text { ND }\end{array}$ \\
\hline
\end{tabular}


TABLE 3.2 (Cont.)

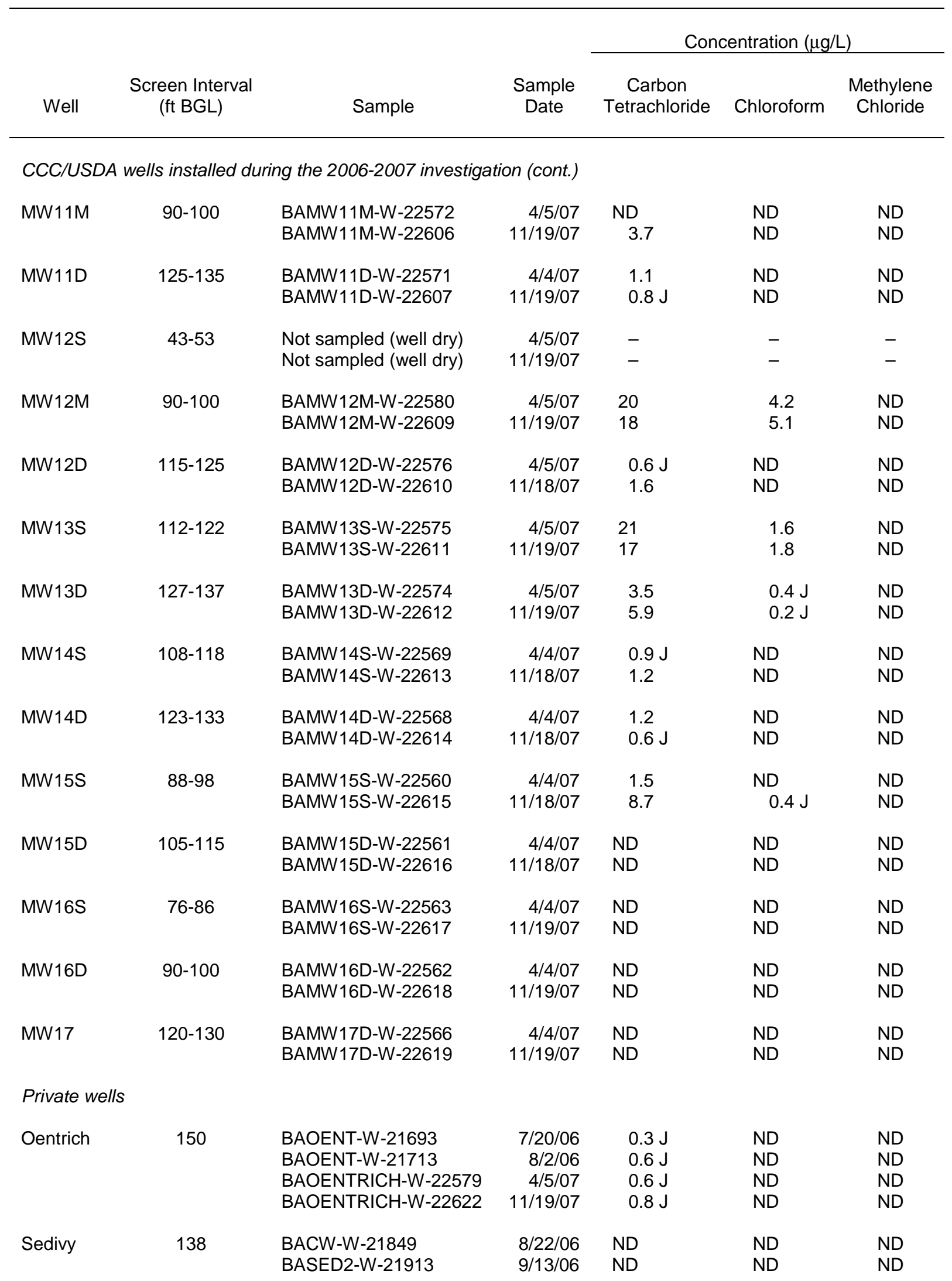


TABLE 3.2 (Cont.)

\begin{tabular}{|c|c|c|c|c|c|c|}
\hline \multirow[b]{2}{*}{ Well } & \multirow[b]{2}{*}{$\begin{array}{l}\text { Screen Interval } \\
\quad(\mathrm{ft} B G L)\end{array}$} & \multirow[b]{2}{*}{ Sample } & \multirow[b]{2}{*}{$\begin{array}{l}\text { Sample } \\
\text { Date }\end{array}$} & \multicolumn{3}{|c|}{ Concentration $(\mu \mathrm{g} / \mathrm{L})$} \\
\hline & & & & $\begin{array}{c}\text { Carbon } \\
\text { Tetrachloride }\end{array}$ & Chloroform & $\begin{array}{c}\text { Methylene } \\
\text { Chloride }\end{array}$ \\
\hline \multicolumn{7}{|c|}{ Private wells (cont.) } \\
\hline Sedivy1 & 90 & Not sampled (well dry) & $9 / 13 / 06$ & - & - & - \\
\hline \multicolumn{7}{|c|}{ Public water supply wells } \\
\hline PWS2 & 155 & $\begin{array}{l}\text { BAPWS2-W-22510 } \\
\text { BAPW2-W-22578 } \\
\text { BAPW2-W-22620 }\end{array}$ & $\begin{array}{r}3 / 9 / 07 \\
4 / 5 / 07 \\
11 / 20 / 07\end{array}$ & $\begin{array}{l}\text { ND } \\
\text { ND } \\
\text { ND }\end{array}$ & $\begin{array}{l}\text { ND } \\
\text { ND } \\
\text { ND }\end{array}$ & $\begin{array}{l}\text { ND } \\
\text { ND } \\
\text { ND }\end{array}$ \\
\hline PWS3 & 160 & $\begin{array}{l}\text { BAPWS3-W-22511 } \\
\text { BAPW3-W-22577 } \\
\text { BAPW3-W-22621 }\end{array}$ & $\begin{array}{r}3 / 9 / 07 \\
4 / 5 / 07 \\
11 / 20 / 07\end{array}$ & $\begin{array}{l}0.2 \mathrm{~J} \\
N D \\
N D\end{array}$ & $\begin{array}{l}\text { ND } \\
\text { ND } \\
\text { ND }\end{array}$ & $\begin{array}{l}\text { ND } \\
\text { ND } \\
\text { ND }\end{array}$ \\
\hline
\end{tabular}

a ND, contaminant not detected at an instrument detection limit of $0.1 \mu \mathrm{g} / \mathrm{L}$.

b Qualifier $\mathrm{J}$ indicates an estimated concentration below the purge-and-trap method quantitation limit of $1.0 \mu \mathrm{g} / \mathrm{L}$. 
Barnes Monitoring Data
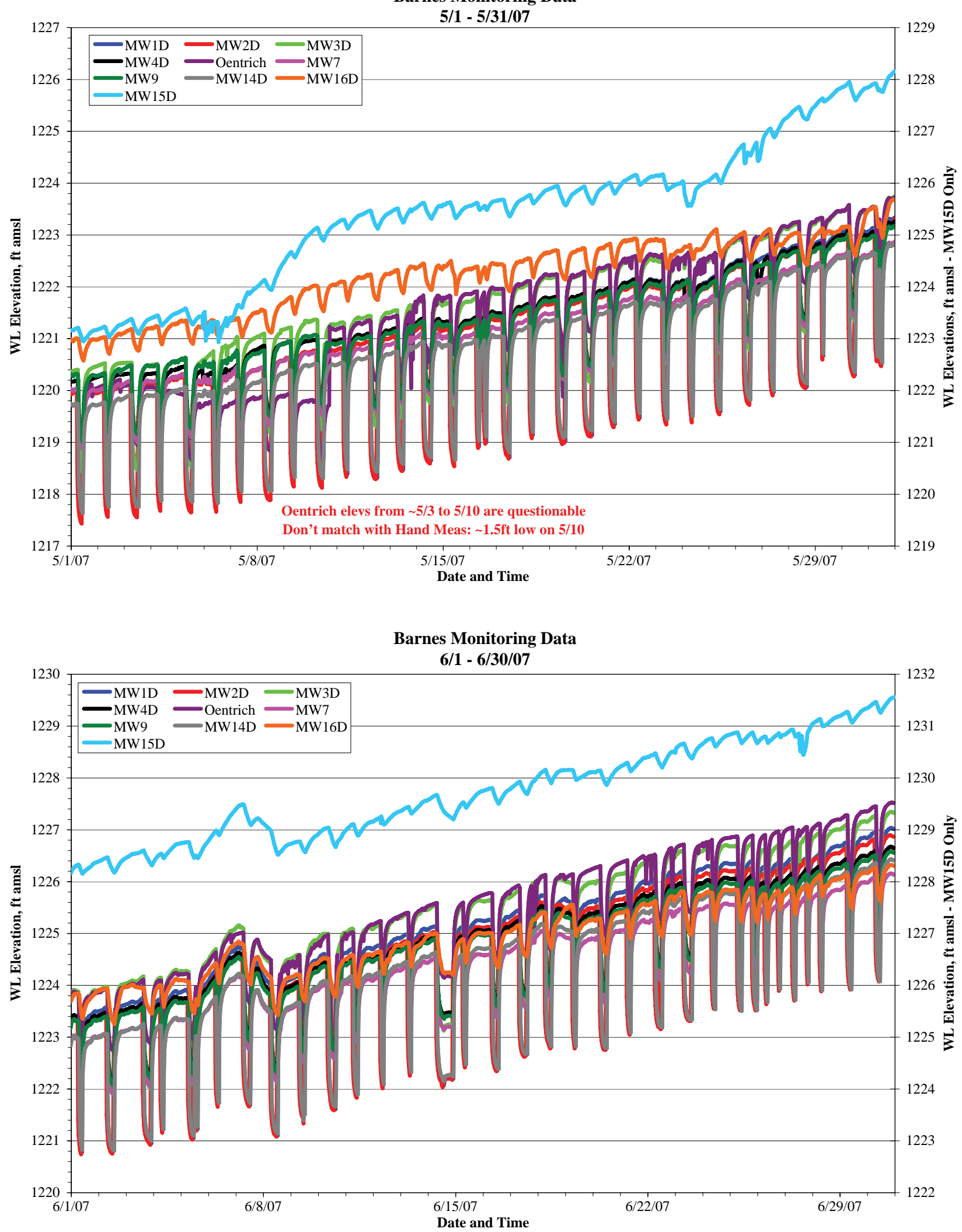

FIGURE 3.1 Hydrographs summarizing monthly results of long-term water level monitoring in wells at Barnes, May 2007 to December 2007. 

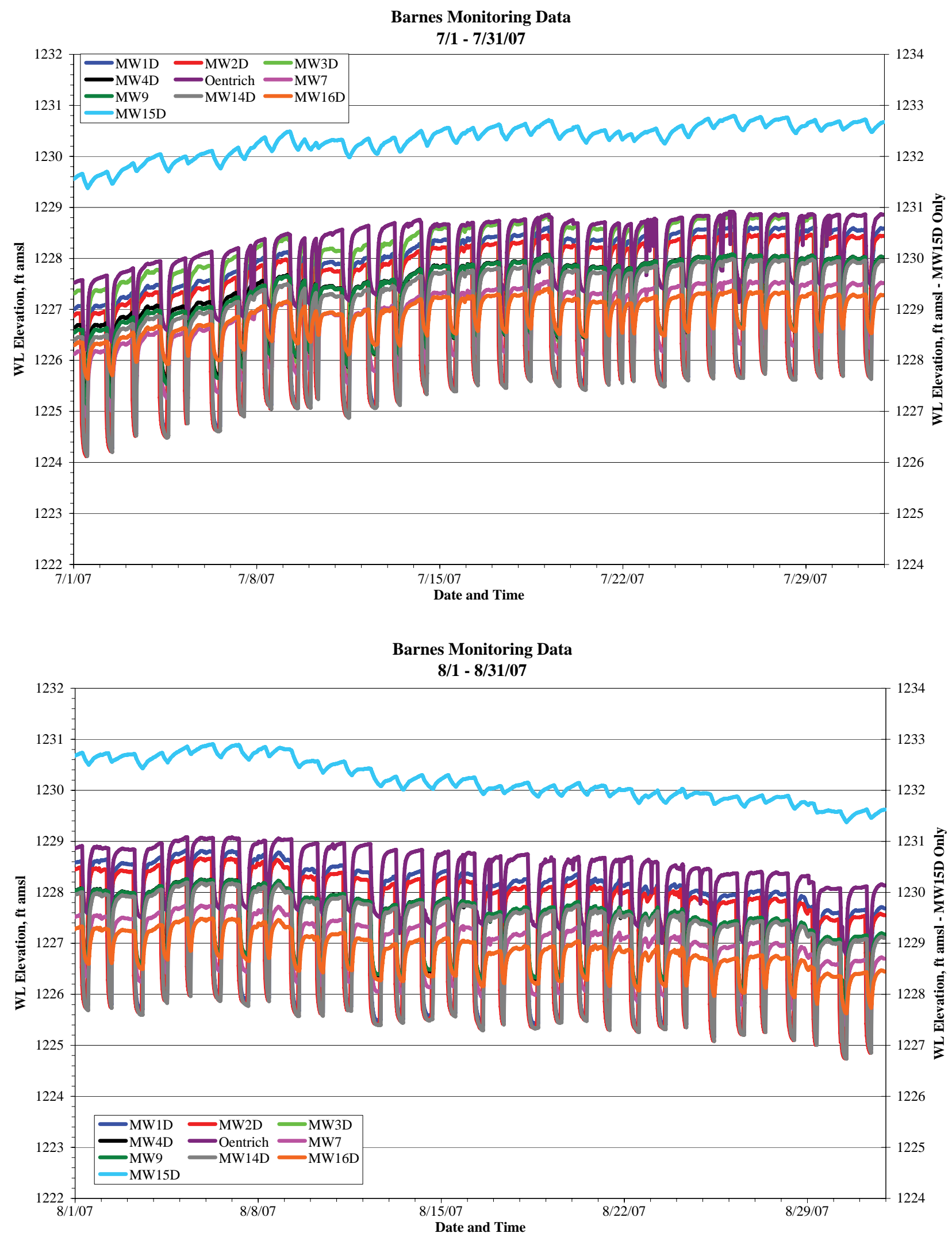

FIGURE 3.1 (Cont.) 
Barnes Monitoring Data

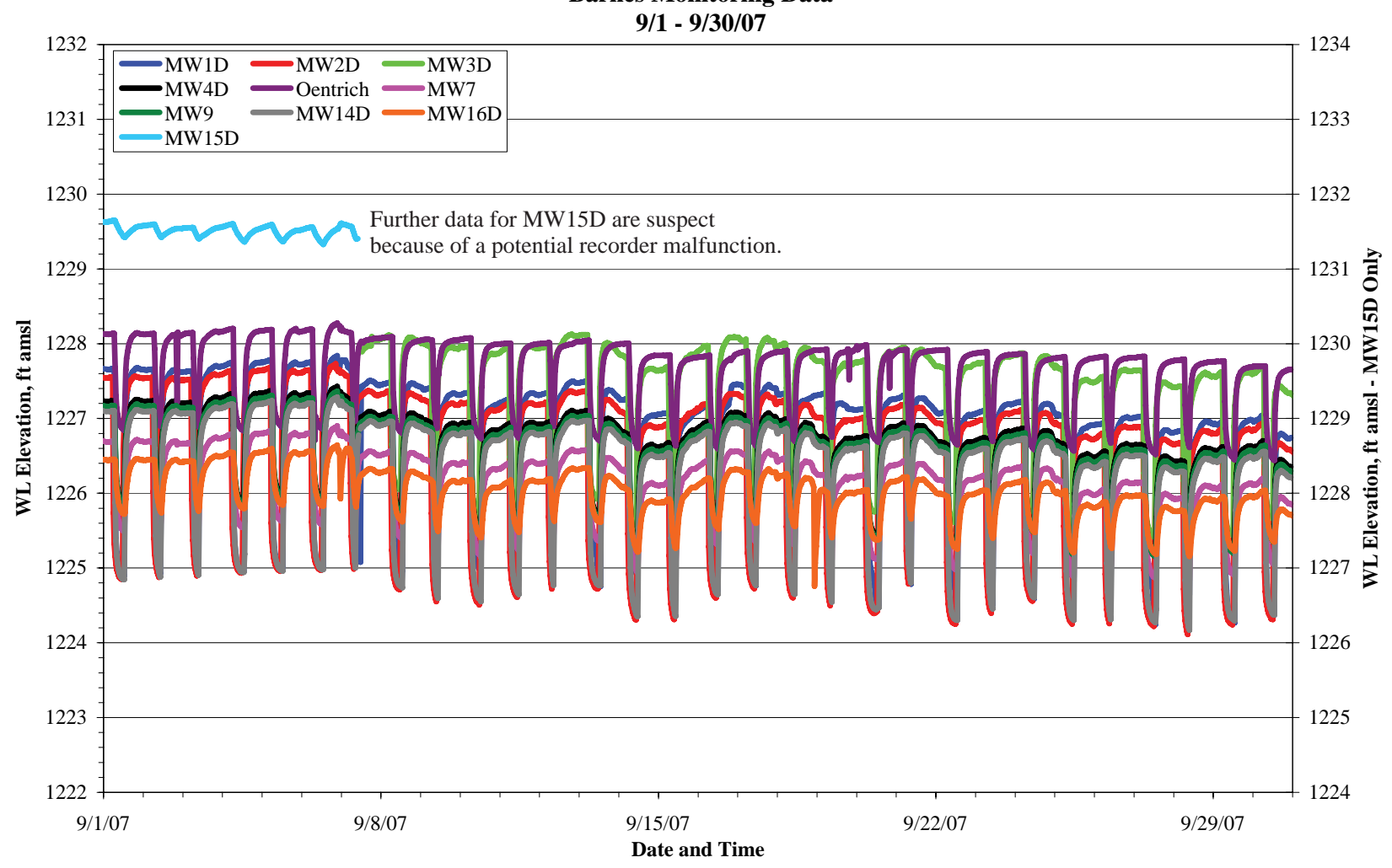

Barnes Monitoring Data

10/1 - 10/31/07

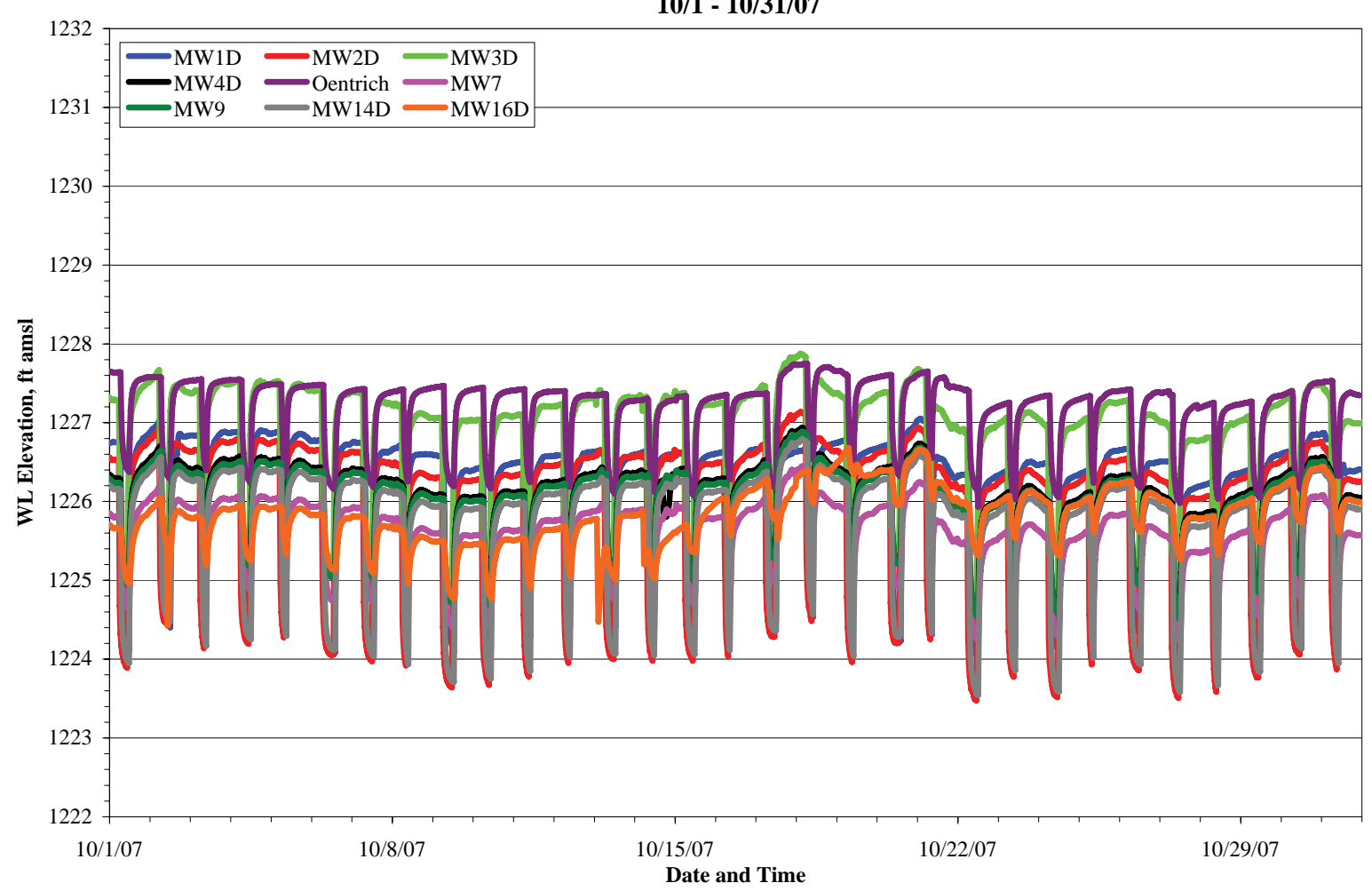

FIGURE 3.1 (Cont.) 

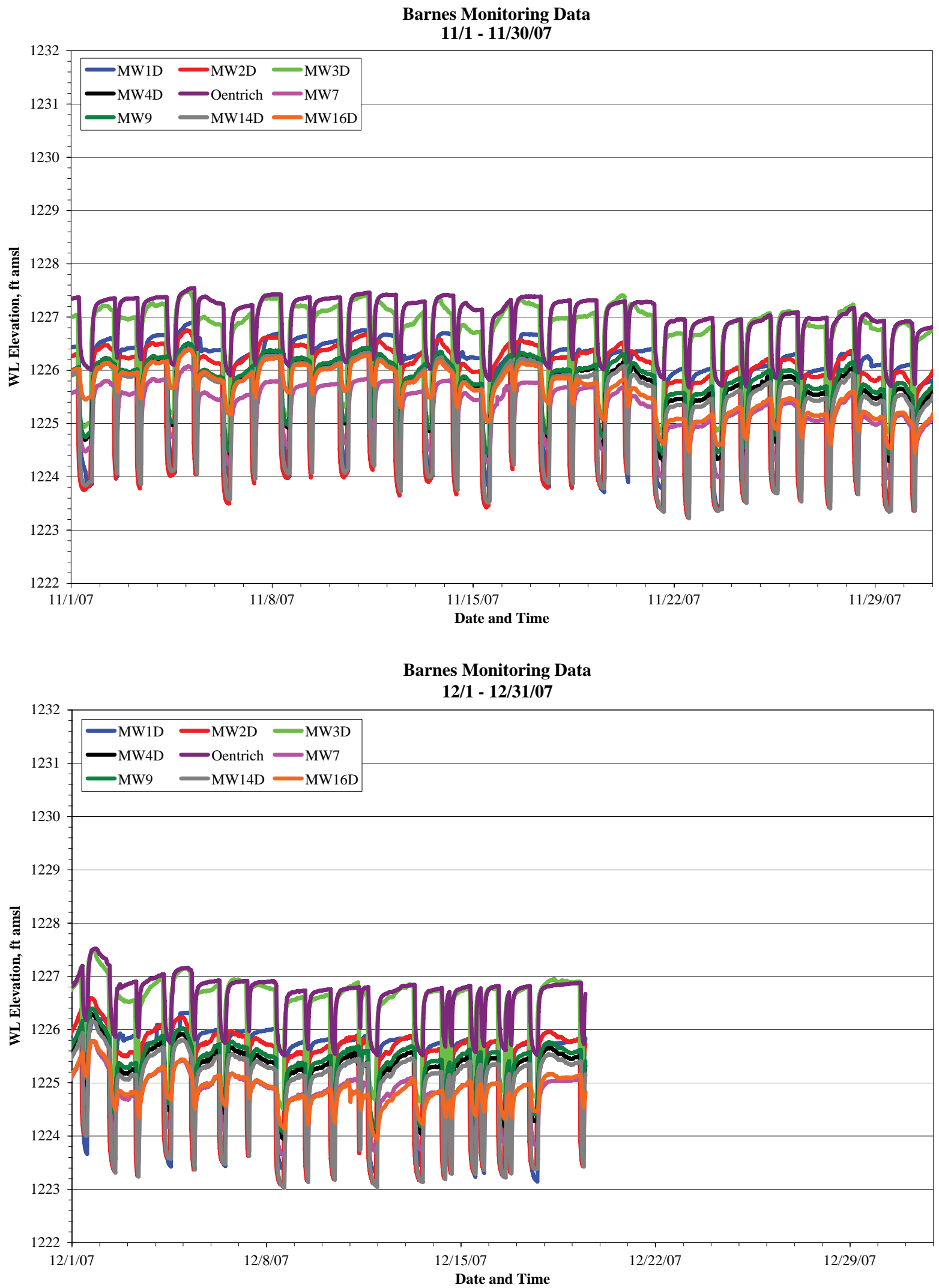

FIGURE 3.1 (Cont.) 


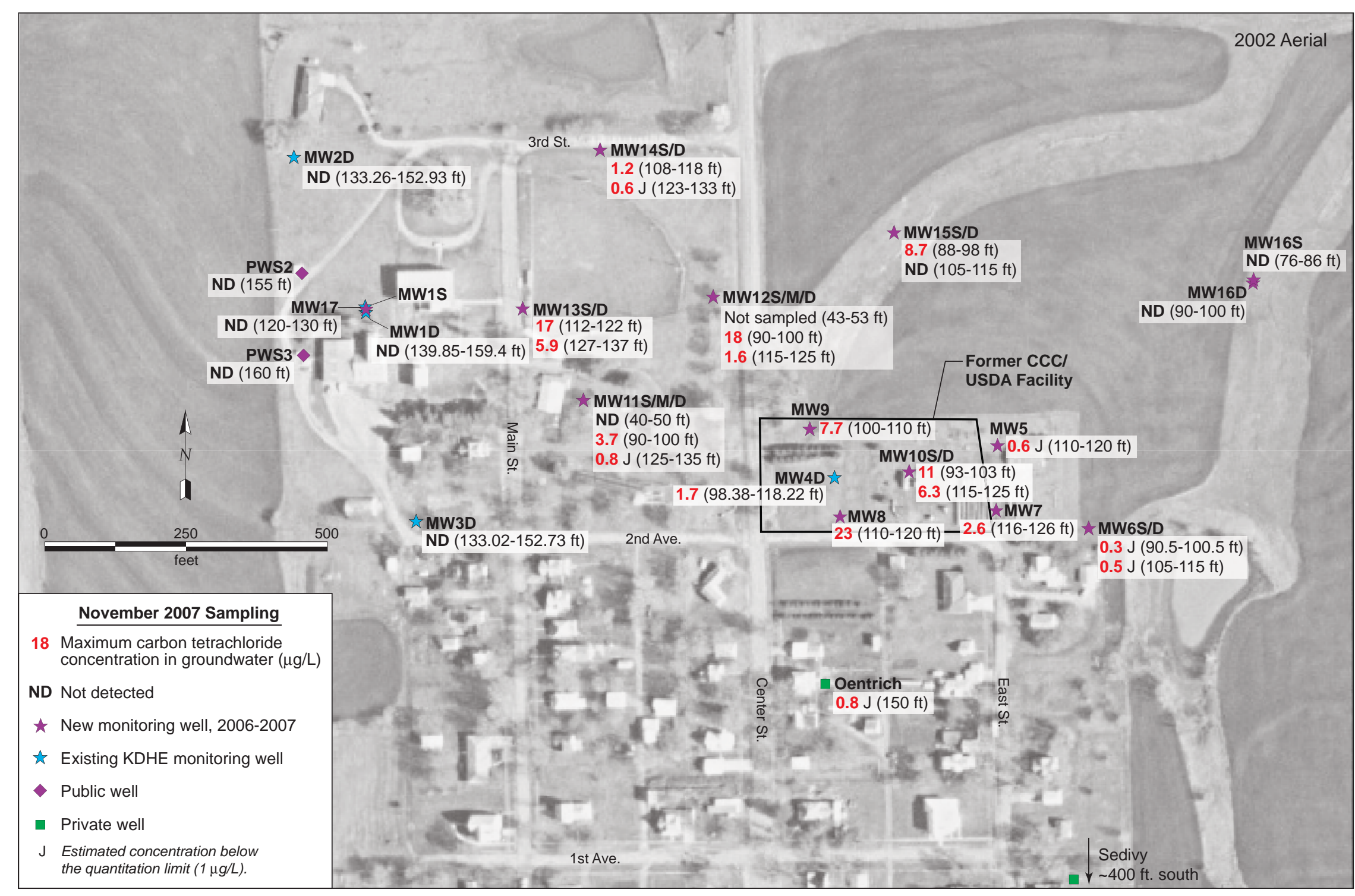

FIGURE 3.2 Analytical results for carbon tetrachloride in groundwater samples collected at Barnes in November 2007. 


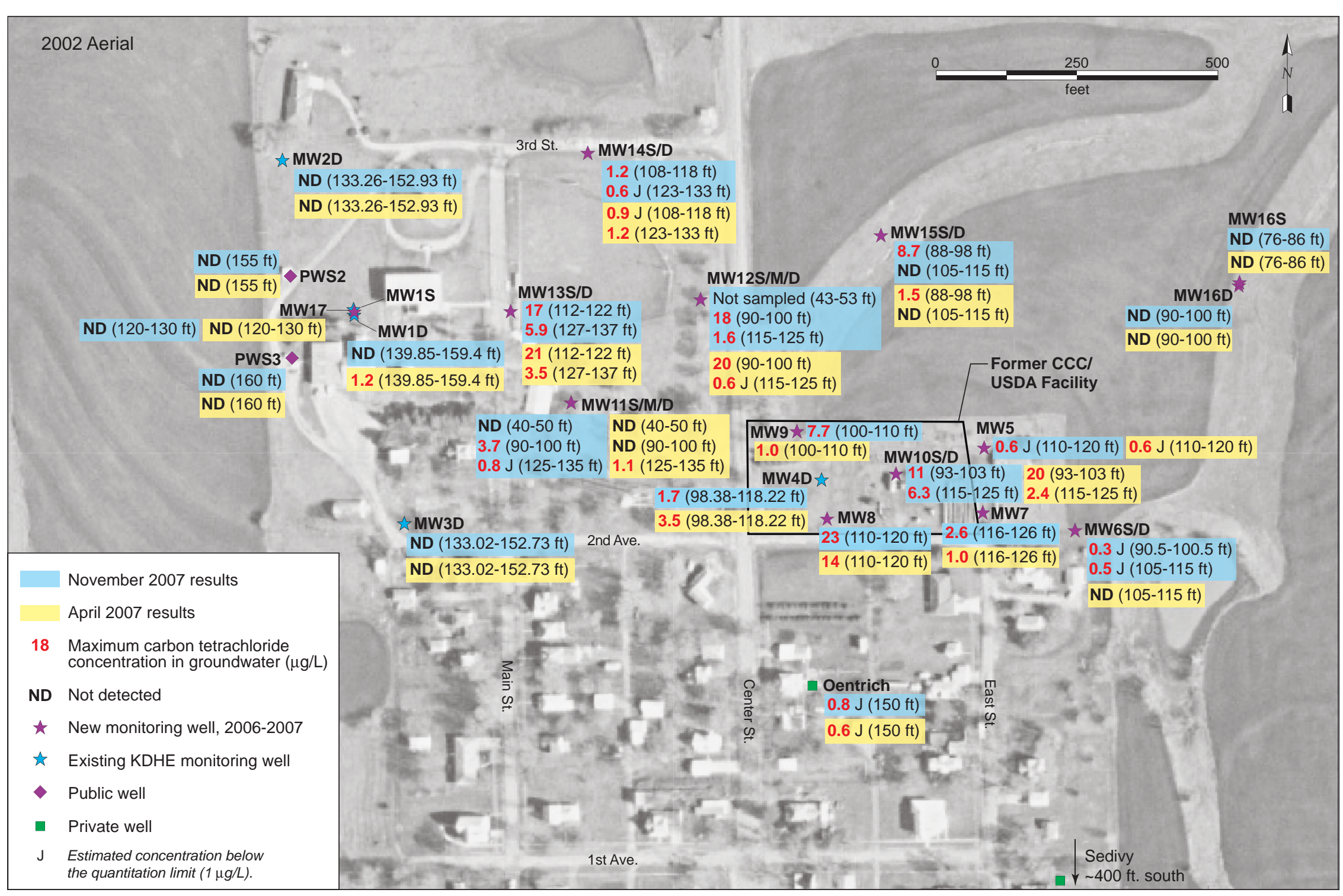

FIGURE 3.3 Analytical results for carbon tetrachloride in groundwater samples collected at Barnes in November 2007 and April 2007. 


\section{Conclusions and Recommendations}

\subsection{Conclusions}

The findings of the November 2007 monitoring event at Barnes support the following conclusions:

- Measurements of groundwater levels obtained manually and through the use of automatic recorders have consistently indicated that the flow direction is strongly influenced by pumping of the public water supply wells. The results continue to indicate the following:

- An apparently radial, relatively weak groundwater flow pattern to the northwest and east-southeast from an area southwest of the former CCC/USDA facility when the public wells are not pumping and

- A strong northwest flow direction, with an increased gradient, when the public wells are pumping. The observed frequency of the public well operation suggests that this northwest flow likely represents the dominant trend influencing the movement of groundwater, and carbon tetrachloride migration, at the site.

- The November 2007 analytical data for groundwater samples are generally consistent with previous results. The data show only minor increases or decreases in contaminant levels at various locations relative to the April 2007 sampling event. The changes are insignificant and fall within the variability expected between sampling events.

\subsection{Recommendations}

The report for the 2006-2007 targeted investigation (Argonne 2007) has been submitted to the KDHE for review. Upon completion of the KDHE review, the CCC/USDA and Argonne will address all comments. With the KDHE's approval, the next phase of work at Barnes 
(quarterly monitoring) will continue to be implemented as recommended in the targeted investigation report (Argonne 2007). 


\section{References}

Argonne, 2002, Final Master Work Plan: Environmental Investigations at Former CCC/USDA Facilities in Kansas, 2002 Revision, ANL/ER/TR-02/2004, prepared for the Commodity Credit Corporation, U.S. Department of Agriculture, Washington, D.C., by Argonne National Laboratory, Argonne, Illinois, December.

Argonne, 2007, Draft Report: Results of the 2007-2007 Investigation of Potential Contamination at the Former CCC/USDA facility in Barnes, Kansas, ANL/EVS/AGEM/TR-07-12, prepared for the Commodity Credit Corporation, U.S. Department of Agriculture, Washington, D.C., by Argonne National Laboratory, Argonne, Illinois, October.

EPA, 1995, Method 524.2: Measurement of Purgeable Organic Compounds in Water by Capillary Column Gas Chromatography/Mass Spectrometry, Revision 4.1, edited by J.W. Munch, National Exposure Research Laboratory, Office of Research and Development, U.S. Environmental Protection Agency, Cincinnati, Ohio.

Sabetha, 2007, General Receipt \#34699 Office of City Clerk, City of Sabetha, Kansas, acknowledging receipt of $\$ 50$ from Argonne National Laboratory "for purged water," December 14. 


\section{Appendix A:}

Sampling Activities and Field Measurements at Barnes in November 2007 
TABLE A.1 Sequence of sampling activities during the November 2007 monitoring event at Barnes, Kansas.

\begin{tabular}{|c|c|c|c|c|c|c|c|c|c|}
\hline $\begin{array}{l}\text { Sample } \\
\text { Date }\end{array}$ & Time & Location & Sample & Medium & Type & $\begin{array}{l}\text { Depth } \\
(\text { ft TOC) })^{\mathrm{a}}\end{array}$ & $\begin{array}{l}\text { Chain of } \\
\text { Custody }\end{array}$ & $\begin{array}{l}\text { Shipping } \\
\text { Date }\end{array}$ & Sample Description \\
\hline $11 / 18 / 07$ & 13:15 & MW12S & BAMW12S-dry & Water & MW & $13.3-23.3$ & - & - & Well dry. \\
\hline $11 / 18 / 07$ & $13: 30$ & MW12D & BAMW12D-W-22610 & Water & MW & $115-125$ & 3575 & $11 / 19 / 07$ & $\begin{array}{l}\text { Static water level from top of casing (TOC) prior to sampling = } \\
102.00 \mathrm{ft} \text {. Depth of well }=124.7 \mathrm{ft} \text {. Sample collected at low flow } \\
\text { after purging of } 11.5 \text { gal with Redi-Flo pump. Quick recharge. }\end{array}$ \\
\hline $11 / 18 / 07$ & 13:31 & MW12D & BAMW12D-W-22610FD & Water & MW & $115-125$ & 3575 & $11 / 19 / 07$ & Replicate of sample BAMW12D-W-22610. \\
\hline $11 / 18 / 07$ & $14: 55$ & MW14S & BAMW14S-W-22613 & Water & MW & $108-118$ & 3575 & $11 / 19 / 07$ & $\begin{array}{l}\text { Static water level from TOC prior to sampling }=106.75 \mathrm{ft} \text {. Depth of } \\
\text { well = } 117.5 \mathrm{ft} \text {. Sample collected at low flow after purging of } \\
6.50 \text { gal with Redi-Flo pump. Quick recharge. }\end{array}$ \\
\hline $11 / 18 / 07$ & $14: 56$ & MW14S & BAMW14S-W-22613FD & Water & MW & $108-118$ & 3575 & $11 / 19 / 07$ & Replicate of sample BAMW14S-W-22613. \\
\hline $11 / 18 / 07$ & 15:38 & MW14D & BAMW14D-W-22614 & Water & MW & $123-133$ & 3575 & $11 / 19 / 07$ & $\begin{array}{l}\text { Static water level from TOC prior to sampling }=107.10 \mathrm{ft} \text {. Depth of } \\
\text { well }=133.3 \mathrm{ft} \text {. Sample collected at low flow after purging of } \\
13.5 \mathrm{gal} \text { with Redi-Flo pump. Quick recharge. }\end{array}$ \\
\hline $11 / 18 / 07$ & $15: 39$ & MW14D & BAMW14D-W-22614FD & Water & MW & $123-133$ & 3575 & $11 / 19 / 07$ & Replicate of sample BAMW14D-W-22614. \\
\hline $11 / 18 / 07$ & $16: 00$ & MW15D & BAMW15D-W-22616 & Water & MW & $105-115$ & 3575 & $11 / 19 / 07$ & $\begin{array}{l}\text { Static water level from TOC prior to sampling }=70.20 \mathrm{ft} \text {. Depth of } \\
\text { well }=117.30 \mathrm{ft} \text {. Sample collected at low flow after purging of } \\
24 \text { gal with Redi-Flo pump. Quick recharge. }\end{array}$ \\
\hline $11 / 18 / 07$ & $16: 40$ & MW1D & BAMW1D-W-22593 & Water & MW & $139.85-159.4$ & 3575 & $11 / 19 / 07$ & $\begin{array}{l}\text { Static water level from TOC prior to sampling }=124.89 \mathrm{ft} \text {. Depth of } \\
\text { well }=156.28 \mathrm{ft} \text {. Sample collected at low flow after purging of } \\
16 \text { gal with Redi-Flo pump. Quick recharge with minimal } \\
\text { drawdown. }\end{array}$ \\
\hline $11 / 18 / 07$ & $16: 45$ & MW1S & BAMW1S-dry & Water & MW & 13.3-23.3 & - & - & Well dry. \\
\hline $11 / 18 / 07$ & $17: 10$ & MW2D & BAMW2D-W-22594 & Water & MW & $133.26-152.93$ & 3575 & $11 / 19 / 07$ & $\begin{array}{l}\text { Static water level from TOC prior to sampling }=122.56 \mathrm{ft} \text {. Depth of } \\
\text { well }=155.0 \mathrm{ft} \text {. Sample collected at low flow after purging of } \\
16.75 \text { gal with Redi-Flo pump. Quick recharge with minimal } \\
\text { drawdown. }\end{array}$ \\
\hline $11 / 18 / 07$ & $17: 37$ & MW15S & BAMW15S-W-22615 & Water & MW & $88-98$ & 3575 & $11 / 19 / 07$ & $\begin{array}{l}\text { Static water level from TOC prior to sampling }=84.33 \mathrm{ft} \text {. Depth of } \\
\text { well = } 96.0 \mathrm{ft} \text {. Sample collected at low flow after purging of } \\
6.25 \mathrm{gal} \text { with Redi-Flo pump. Quick recharge. }\end{array}$ \\
\hline $11 / 18 / 07$ & $18: 00$ & QC & BAQCTB-W-22625 & Water & TB & - & 4777 & $11 / 20 / 07$ & $\begin{array}{l}\text { Trip blank sent to Envirosystems, Inc., for verification organic } \\
\text { analysis with three water samples listed on chain-of-custody } \\
\text { (COC) form } 4777 \text {. The samples (BAMW12D-W-22610, } \\
\text { BAMW14S-W-22613, BAMW14D-W-22614) were received by } \\
\text { the laboratory but were not analyzed. }\end{array}$ \\
\hline $11 / 18 / 07$ & $20: 30$ & QC & BAQCTB-W-22623 & Water & TB & - & 3575 & $11 / 19 / 07$ & $\begin{array}{l}\text { Trip blank sent to the AGEM Laboratory for organic analyses with } \\
\text { water samples listed on COCs } 3575,3573 \text {, and } 3572 \text {. }\end{array}$ \\
\hline $11 / 19 / 07$ & 8:02 & MW17 & BAMW17D-W-22619 & Water & MW & $120-130$ & 3572 & $11 / 19 / 07$ & $\begin{array}{l}\text { Static water level from TOC prior to sampling }=102.68 \mathrm{ft} \text {. Depth of } \\
\text { well }=132.0 \mathrm{ft} \text {. Sample collected at low flow after purging of } \\
15.5 \mathrm{gal} \text { with Redi-Flo pump. Quick recharge. }\end{array}$ \\
\hline $11 / 19 / 07$ & $8: 55$ & MW4D & BAMW4D-W-22596 & Water & MW & $98.38-118.22$ & 3573 & $11 / 19 / 07$ & $\begin{array}{l}\text { Static water level from TOC prior to sampling }=101.39 \mathrm{ft} \text {. Depth of } \\
\text { well = } 115.4 \mathrm{ft} \text {. Sample collected at low flow after purging of } \\
7.5 \mathrm{gal} \text { with Redi-Flo pump. Quick recharge. }\end{array}$ \\
\hline
\end{tabular}


TABLE A.1 (Cont.)

\begin{tabular}{|c|c|c|c|c|c|c|c|c|c|}
\hline $\begin{array}{l}\text { Sample } \\
\text { Date }\end{array}$ & Time & Location & Sample & Medium & Type & $\begin{array}{l}\text { Depth } \\
(\mathrm{ft} \text { TOC })^{\mathrm{a}}\end{array}$ & $\begin{array}{l}\text { Chain of } \\
\text { Custody }\end{array}$ & $\begin{array}{l}\text { Shipping } \\
\text { Date }\end{array}$ & Sample Description \\
\hline $11 / 19 / 07$ & 9:00 & MW3D & BAMW3D-W-22595 & Water & MW & $133.02-152.73$ & 3573 & $11 / 19 / 07$ & $\begin{array}{l}\text { Static water level from TOC prior to sampling }=126.25 \mathrm{ft} \text {. Depth of } \\
\text { well }=157.00 \mathrm{ft} \text {. Sample collected at low flow after purging of } \\
15.5 \mathrm{gal} \text { with Redi-Flo pump. Quick recharge. }\end{array}$ \\
\hline $11 / 19 / 07$ & $9: 15$ & MW5 & BAMW5-W-22597 & Water & MW & $110-120$ & 3573 & $11 / 19 / 07$ & $\begin{array}{l}\text { Static water level from TOC prior to sampling }=102.78 \mathrm{ft} \text {. Depth of } \\
\text { well }=120.0 \mathrm{ft} \text {. Sample collected at low flow after purging of } \\
9.25 \text { gal with Redi-Flo pump. Quick recharge. }\end{array}$ \\
\hline $11 / 19 / 07$ & $9: 30$ & MW6S & BAMW6S-W-22598 & Water & MW & $90.5-100.5$ & 3573 & $11 / 19 / 07$ & $\begin{array}{l}\text { Static water level from TOC prior to sampling }=96.10 \mathrm{ft} \text {. Depth of } \\
\text { well }=102.44 \mathrm{ft} \text {. Sample collected at low flow after purging of } \\
4.5 \mathrm{gal} \text { with Redi-Flo pump. Slow recharge. }\end{array}$ \\
\hline $11 / 19 / 07$ & $9: 35$ & MW6D & BAMW6D-W-22599 & Water & MW & $105-115$ & 3573 & $11 / 19 / 07$ & $\begin{array}{l}\text { Static water level from TOC prior to sampling }=98.50 \mathrm{ft} \text {. Depth of } \\
\text { well }=117.4 \mathrm{ft} \text {. Sample collected at low flow after purging of } 5 \text { gal } \\
\text { with Redi-Flo pump. Slow recharge. }\end{array}$ \\
\hline $11 / 19 / 07$ & $9: 40$ & MW16S & BAMW16S-W-22617 & Water & MW & $76-86$ & 3572 & $11 / 19 / 07$ & $\begin{array}{l}\text { Static water level from TOC prior to sampling }=75.30 \mathrm{ft} \text {. Depth of } \\
\text { well }=83.4 \mathrm{ft} \text {. Sample collected at low flow after purging of } \\
4.5 \mathrm{gal} \text { with Redi-Flo pump. Slow recharge. }\end{array}$ \\
\hline $11 / 19 / 07$ & $9: 45$ & MW16D & BAMW16D-W-22618 & Water & MW & $90-100$ & 3572 & $11 / 19 / 07$ & $\begin{array}{l}\text { Static water level from TOC prior to sampling }=74.50 \mathrm{ft} \text {. Depth of } \\
\text { well }=101.30 \mathrm{ft} \text {. Sample collected at low flow after purging of } \\
13.75 \text { gal with Redi-Flo pump. Slower recharge. }\end{array}$ \\
\hline $11 / 19 / 07$ & $10: 40$ & MW8 & BAMW8-W-22601 & Water & MW & $110-120$ & 3573 & $11 / 19 / 07$ & $\begin{array}{l}\text { Static water level from TOC prior to sampling }=105.17 \mathrm{ft} \text {. Depth of } \\
\text { well }=119.0 \mathrm{ft} \text {. Sample collected at low flow after purging of } 7 \mathrm{gal} \\
\text { with Redi-Flo pump. Quick recharge. }\end{array}$ \\
\hline $11 / 19 / 07$ & $11: 30$ & MW11S & BAMW11S-W-22605 & Water & MW & $40-50$ & 3573 & $11 / 19 / 07$ & $\begin{array}{l}\text { Static water level from TOC prior to sampling }=29.20 \mathrm{ft} \text {. Depth of } \\
\text { well }=49.80 \mathrm{ft} \text {. Sample collected at low flow after purging of } \\
3.5 \text { gal with Redi-Flo pump. Quick recharge. }\end{array}$ \\
\hline $11 / 19 / 07$ & $11: 35$ & MW11M & BAMW11M-W-22606 & Water & MW & $90-100$ & 3573 & $11 / 19 / 07$ & $\begin{array}{l}\text { Static water level from TOC prior to sampling }=82.33 \mathrm{ft} \text {. Depth of } \\
\text { well }=102.0 \mathrm{ft} \text {. Sample collected at low flow after purging of } \\
10.5 \text { gal with Redi-Flo pump. Quick recharge. }\end{array}$ \\
\hline $11 / 19 / 07$ & $12: 00$ & MW11D & BAMW11D-W-22607 & Water & MW & $125-135$ & 3573 & $11 / 19 / 07$ & $\begin{array}{l}\text { Static water level from TOC prior to sampling }=112.46 \mathrm{ft} \text {. Depth of } \\
\text { well = } 135.3 \mathrm{ft} . \text { Sample collected at low flow after purging of } \\
11.75 \mathrm{gal} \text { with Redi-Flo pump. Quick recharge. }\end{array}$ \\
\hline $11 / 19 / 07$ & $12: 10$ & Oentrich & BAOENTRICH-W-22622 & Water & DW & 150 & 3573 & $11 / 19 / 07$ & $\begin{array}{l}\text { Unable to access well head. Depth of well approximately } 150 \mathrm{ft} \text {. } \\
\text { Sample collected after pump had run for about } 10 \mathrm{~min} .\end{array}$ \\
\hline $11 / 19 / 07$ & $12: 50$ & MW13D & BAMW13D-W-22612 & Water & MW & $127-137$ & 3572 & $11 / 19 / 07$ & $\begin{array}{l}\text { Static water level from TOC prior to sampling }=117.83 \mathrm{ft} \text {. Depth of } \\
\text { well }=136.2 \mathrm{ft} . \text { Sample collected at low flow after purging of } \\
9.5 \text { gal with Redi-Flo pump. Quick recharge. }\end{array}$ \\
\hline $11 / 19 / 07$ & 13:05 & MW9 & BAMW9-W-22602 & Water & MW & $100-110$ & 3573 & $11 / 19 / 07$ & $\begin{array}{l}\text { Static water level from TOC prior to sampling }=97.20 \mathrm{ft} \text {. Depth of } \\
\text { well }=115.25 \mathrm{ft} \text {. Sample collected at low flow after purging of } \\
9.25 \text { gal with Redi-Flo pump. Quick recharge. }\end{array}$ \\
\hline $11 / 19 / 07$ & $13: 10$ & MW7 & BAMW7-W-22600 & Water & MW & $116-126$ & 3573 & $11 / 19 / 07$ & $\begin{array}{l}\text { Static water level from TOC prior to sampling }=105.5 \mathrm{ft} \text {. Depth of } \\
\text { well }=125.5 \mathrm{ft} \text {. Sample collected at low flow after purging of } \\
10 \text { gal with Redi-Flo pump. Quick recharge. }\end{array}$ \\
\hline
\end{tabular}


TABLE A.1 (Cont.)

\begin{tabular}{|c|c|c|c|c|c|c|c|c|c|}
\hline $\begin{array}{l}\text { Sample } \\
\text { Date }\end{array}$ & Time & Location & Sample & Medium & Type & $\begin{array}{l}\text { Depth } \\
(\mathrm{ft} \text { TOC) })^{\mathrm{a}}\end{array}$ & $\begin{array}{l}\text { Chain of } \\
\text { Custody }\end{array}$ & $\begin{array}{l}\text { Shipping } \\
\text { Date }\end{array}$ & Sample Description \\
\hline $11 / 19 / 07$ & $14: 00$ & MW13S & BAMW13S-W-22611 & Water & MW & $112-122$ & 3572 & $11 / 19 / 07$ & $\begin{array}{l}\text { Static water level from TOC prior to sampling }=92.23 \mathrm{ft} \text {. Depth of } \\
\text { well = } 122.3 \mathrm{ft} \text {. Sample collected at low flow after purging of } \\
15.5 \text { gal with Redi-Flo pump. Quick recharge. }\end{array}$ \\
\hline $11 / 19 / 07$ & $14: 10$ & MW12M & BAMW12M-W-22609 & Water & MW & $90-100$ & 3573 & $11 / 19 / 07$ & $\begin{array}{l}\text { Static water level from TOC prior to sampling }=74.50 \mathrm{ft} \text {. Depth of } \\
\text { well }=99.0 \mathrm{ft} \text {. Sample collected at low flow after purging of } \\
12.5 \mathrm{gal} \text { with Redi-Flo pump. Quick recharge. }\end{array}$ \\
\hline $11 / 19 / 07$ & $15: 00$ & MW10S & BAMW10S-W-22603 & Water & MW & $93-103$ & 3573 & $11 / 19 / 07$ & $\begin{array}{l}\text { Static water level from TOC prior to sampling }=77.81 \mathrm{ft} \text {. Depth of } \\
\text { well }=104.75 \mathrm{ft} \text {. Sample collected at low flow after purging of } \\
13.5 \text { gal with Redi-Flo pump. Quick recharge. }\end{array}$ \\
\hline $11 / 19 / 07$ & $15: 05$ & MW10D & BAMW10D-W-22604 & Water & MW & $115-125$ & 3573 & $11 / 19 / 07$ & $\begin{array}{l}\text { Static water level from TOC prior to sampling = } 106.22 \mathrm{ft} \text {. Depth of } \\
\text { well }=127.5 \mathrm{ft} \text {. Sample collected at low flow after purging of } \\
11.5 \mathrm{gal} \text { with Redi-Flo pump. Quick recharge. }\end{array}$ \\
\hline $11 / 20 / 07$ & $8: 35$ & PWS3 & BAPW3-W-22621 & Water & PW & 160 & 4775 & $11 / 20 / 07$ & Pump running at time of sampling. \\
\hline $11 / 20 / 07$ & $8: 45$ & PWS2 & BAPW2-W-22620 & Water & PW & 155 & 4775 & $11 / 20 / 07$ & Pump running at time of sampling. \\
\hline $11 / 20 / 07$ & 9:00 & QC & BAWW1-W-22626 & Water & BT & - & 1134204 & $11 / 20 / 07$ & $\begin{array}{l}\text { Waste purge water sample sent to Pace Analytical Services, Inc., } \\
\text { for VOCs (including ethylene dibromide) and nitrate analyses, } \\
\text { with samples listed on Pace COC } 1134204 .\end{array}$ \\
\hline $11 / 20 / 07$ & $16: 00$ & QC & BAQCTB-W-22624 & Water & TB & - & 4775 & $11 / 20 / 07$ & $\begin{array}{l}\text { Trip blank sent to the AGEM Laboratory for organic analyses with } \\
\text { water samples listed on COC } 4775 \text {. }\end{array}$ \\
\hline
\end{tabular}

a Depth is in feet below the top of the well casing. 
TABLE A.2 Field measurements for groundwater samples collected at Barnes, July 2006 to November 2007.

\begin{tabular}{|c|c|c|c|c|c|}
\hline Well & $\begin{array}{l}\text { Screen Interval } \\
\quad(\mathrm{ft} B G L)\end{array}$ & $\begin{array}{l}\text { Sample } \\
\text { Date }\end{array}$ & $\begin{array}{l}\text { Temperature } \\
\left({ }^{\circ} \mathrm{C}\right)\end{array}$ & $\mathrm{pH}$ & $\begin{array}{l}\text { Conductivity } \\
\qquad(\mu \mathrm{S} / \mathrm{cm})\end{array}$ \\
\hline \multicolumn{6}{|c|}{ Existing KDHE monitoring wells } \\
\hline MW1S & 13.3-23.3 & $\begin{array}{r}7 / 19 / 06 \\
4 / 4 / 07 \\
11 / 18 / 07\end{array}$ & $\begin{array}{r}-{ }^{a} \\
-\end{array}$ & $\begin{array}{l}- \\
- \\
-\end{array}$ & $\begin{array}{l}- \\
- \\
-\end{array}$ \\
\hline MW1D & $139.85-159.4$ & $\begin{array}{r}7 / 19 / 06 \\
4 / 4 / 07 \\
11 / 18 / 07\end{array}$ & $\begin{array}{l}22.8 \\
15.7 \\
12.7\end{array}$ & $\begin{array}{l}7.15 \\
6.30 \\
7.62\end{array}$ & $\begin{array}{l}945 \\
855 \\
712\end{array}$ \\
\hline MW2D & $133.26-152-93$ & $\begin{array}{r}7 / 19 / 06 \\
4 / 4 / 07 \\
11 / 18 / 07\end{array}$ & $\begin{array}{l}24.7 \\
15.1 \\
12.1\end{array}$ & $\begin{array}{l}7.72 \\
6.32 \\
6.96\end{array}$ & $\begin{array}{r}946 \\
887 \\
1448\end{array}$ \\
\hline MW3D & $133.02-152.73$ & $\begin{array}{r}7 / 19 / 06 \\
4 / 4 / 07 \\
11 / 19 / 07\end{array}$ & $\begin{array}{l}23.0 \\
15.6 \\
10.5\end{array}$ & $\begin{array}{l}7.06 \\
6.37 \\
7.16\end{array}$ & $\begin{array}{r}976 \\
989 \\
1093\end{array}$ \\
\hline MW4D & $98.38-118.22$ & $\begin{array}{r}7 / 20 / 06 \\
4 / 6 / 07 \\
11 / 19 / 07\end{array}$ & $\begin{array}{l}23.5 \\
11.3 \\
15.7\end{array}$ & $\begin{array}{l}6.26 \\
6.21 \\
6.98\end{array}$ & $\begin{array}{r}968 \\
1018 \\
1022\end{array}$ \\
\hline \multicolumn{6}{|c|}{ CCC/USDA wells installed during the 2006-2007 investigation } \\
\hline MW5 & $110-120$ & $\begin{array}{r}4 / 6 / 07 \\
11 / 19 / 07\end{array}$ & $\begin{array}{l}13.9 \\
15.2\end{array}$ & $\begin{array}{l}6.17 \\
6.74\end{array}$ & $\begin{array}{l}1705 \\
3070\end{array}$ \\
\hline MW6S & $90.5-100.5$ & $\begin{array}{r}4 / 4 / 07 \\
11 / 19 / 07\end{array}$ & $\overline{12.0}$ & $\overline{7}-60$ & $72 \overline{3}$ \\
\hline MW6D & $105-115$ & $\begin{array}{r}4 / 5 / 07 \\
11 / 19 / 07\end{array}$ & $\begin{array}{r}6.2 \\
13.6\end{array}$ & $\begin{array}{l}6.11 \\
7.00\end{array}$ & $\begin{array}{r}936 \\
1103\end{array}$ \\
\hline MW7 & $116-126$ & $\begin{array}{r}4 / 6 / 07 \\
11 / 19 / 07\end{array}$ & $\begin{array}{l}14.1 \\
14.6\end{array}$ & $\begin{array}{l}6.30 \\
7.16\end{array}$ & $\begin{array}{r}1051 \\
890\end{array}$ \\
\hline MW8 & $110-120$ & $\begin{array}{r}4 / 6 / 07 \\
11 / 19 / 07\end{array}$ & $\begin{array}{l}12.1 \\
14.6\end{array}$ & $\begin{array}{l}6.23 \\
7.03\end{array}$ & $\begin{array}{l}974 \\
909\end{array}$ \\
\hline MW9 & $100-110$ & $\begin{array}{r}4 / 5 / 07 \\
11 / 19 / 07\end{array}$ & $\begin{array}{l}12.9 \\
16.5\end{array}$ & $\begin{array}{l}6.20 \\
7.21\end{array}$ & $\begin{array}{r}976 \\
1066\end{array}$ \\
\hline MW10S & 93-103 & $\begin{array}{r}4 / 6 / 07 \\
11 / 19 / 07\end{array}$ & $\begin{array}{l}13.2 \\
14.5\end{array}$ & $\begin{array}{l}6.36 \\
7.22\end{array}$ & $\begin{array}{r}1004 \\
942\end{array}$ \\
\hline MW10D & $115-125$ & $\begin{array}{r}4 / 6 / 07 \\
11 / 19 / 07\end{array}$ & $\begin{array}{l}12.1 \\
14.5\end{array}$ & $\begin{array}{l}6.21 \\
7.42\end{array}$ & $\begin{array}{r}992 \\
1175\end{array}$ \\
\hline MW11S & $40-50$ & $\begin{array}{r}4 / 4 / 07 \\
11 / 19 / 07\end{array}$ & $\begin{array}{l}12.8 \\
11.2\end{array}$ & $\begin{array}{l}6.14 \\
7.15\end{array}$ & $\begin{array}{l}1027 \\
1174\end{array}$ \\
\hline MW11M & $90-100$ & $\begin{array}{r}4 / 5 / 07 \\
11 / 19 / 07\end{array}$ & $\begin{array}{r}7.5 \\
11.9\end{array}$ & $\begin{array}{l}7.60 \\
7.17\end{array}$ & $\begin{array}{l}1097 \\
1144\end{array}$ \\
\hline
\end{tabular}


TABLE A.2 (Cont.)

\begin{tabular}{cccccc}
\hline Well & $\begin{array}{c}\text { Screen Interval } \\
(\mathrm{ft} \mathrm{BGL})\end{array}$ & $\begin{array}{c}\text { Sample } \\
\text { Date }\end{array}$ & $\begin{array}{c}\text { Temperature } \\
\left({ }^{\circ} \mathrm{C}\right)\end{array}$ & $\mathrm{pH}$ & $\begin{array}{c}\text { Conductivity } \\
(\mu \mathrm{S} / \mathrm{cm})\end{array}$ \\
\hline
\end{tabular}

CCC/USDA wells installed during the 2006-2007 investigation (cont.)

\begin{tabular}{|c|c|c|c|c|}
\hline MW11D & $125-135$ & $\begin{array}{r}4 / 4 / 07 \\
11 / 19 / 07\end{array}$ & $\begin{array}{l}13.8 \\
13.1\end{array}$ & $\begin{array}{l}6.18 \\
7.22\end{array}$ \\
\hline MW12S & $43-53$ & $\begin{array}{r}4 / 5 / 07 \\
11 / 19 / 07\end{array}$ & - & - \\
\hline MW12M & $90-100$ & $\begin{array}{r}4 / 5 / 07 \\
11 / 19 / 07\end{array}$ & $\begin{array}{l}12.6 \\
14.9\end{array}$ & $\begin{array}{l}6.42 \\
7.13\end{array}$ \\
\hline MW12D & $115-125$ & $\begin{array}{r}4 / 5 / 07 \\
11 / 18 / 07\end{array}$ & $\begin{array}{l}14.0 \\
15.6\end{array}$ & $\begin{array}{l}6.36 \\
6.95\end{array}$ \\
\hline MW13S & $112-122$ & $\begin{array}{r}4 / 5 / 07 \\
11 / 19 / 07\end{array}$ & $\begin{array}{r}9.8 \\
16.5\end{array}$ & $\begin{array}{l}6.42 \\
7.21\end{array}$ \\
\hline MW13D & $127-137$ & $\begin{array}{r}4 / 5 / 07 \\
11 / 19 / 07\end{array}$ & $\begin{array}{l}14.9 \\
17.0\end{array}$ & $\begin{array}{l}6.25 \\
7.00\end{array}$ \\
\hline MW14S & $108-118$ & $\begin{array}{r}4 / 4 / 07 \\
11 / 18 / 07\end{array}$ & $\begin{array}{l}13.4 \\
12.9\end{array}$ & $\begin{array}{l}6.50 \\
7.26\end{array}$ \\
\hline MW14D & $123-133$ & $\begin{array}{r}4 / 4 / 07 \\
11 / 18 / 07\end{array}$ & $\begin{array}{l}14.7 \\
13.2\end{array}$ & $\begin{array}{l}6.34 \\
7.47\end{array}$ \\
\hline MW15S & $88-98$ & $\begin{array}{r}4 / 4 / 07 \\
11 / 18 / 07\end{array}$ & $\begin{array}{l}13.1 \\
13.9\end{array}$ & $\begin{array}{l}8.03 \\
-\end{array}$ \\
\hline MW15D & $105-115$ & $\begin{array}{r}4 / 4 / 07 \\
11 / 18 / 07\end{array}$ & $\begin{array}{l}14.8 \\
13.1\end{array}$ & $\begin{array}{l}6.15 \\
6.85\end{array}$ \\
\hline MW16S & $76-86$ & $\begin{array}{r}4 / 4 / 07 \\
11 / 19 / 07\end{array}$ & $\begin{array}{l}12.8 \\
15.0\end{array}$ & $\begin{array}{l}6.35 \\
6.94\end{array}$ \\
\hline MW16D & $90-100$ & $\begin{array}{r}4 / 4 / 07 \\
11 / 19 / 07\end{array}$ & $\begin{array}{l}14.1 \\
12.5\end{array}$ & $\begin{array}{l}6.17 \\
6.78\end{array}$ \\
\hline MW17 & $120-130$ & $\begin{array}{r}4 / 4 / 07 \\
11 / 19 / 07\end{array}$ & $\begin{array}{r}16.0 \\
8.3\end{array}$ & $\begin{array}{l}6.44 \\
7.15\end{array}$ \\
\hline
\end{tabular}

Private wells

\begin{tabular}{lrrcrr} 
Oentrich & 150 & $7 / 20 / 06$ & - & - & - \\
& & $8 / 2 / 06$ & - & - & - \\
& & $4 / 5 / 07$ & - & - & - \\
& & $11 / 19 / 07$ & 12.1 & 8.26 & 1830 \\
\multirow{2}{*}{ Sedivy } & 138 & $8 / 22 / 06$ & - & - & - \\
& & $9 / 13 / 06$ & 22.5 & 6.57 & 739 \\
Sedivy1 & 90 & $9 / 13 / 06$ & - & - & -
\end{tabular}


TABLE A.2 (Cont.)

\begin{tabular}{lcrccc}
\hline Well & $\begin{array}{c}\text { Screen Interval } \\
(\mathrm{ft} B G L)\end{array}$ & $\begin{array}{c}\text { Sample } \\
\text { Date }\end{array}$ & $\begin{array}{c}\text { Temperature } \\
\left({ }^{\circ} \mathrm{C}\right)\end{array}$ & $\mathrm{pH}$ & $\begin{array}{c}\text { Conductivity } \\
(\mu \mathrm{S} / \mathrm{cm})\end{array}$ \\
\hline \multicolumn{2}{l}{ Public water supply wells } & & & & \\
PWS2 & 155 & $3 / 9 / 07$ & - & - & - \\
& & $4 / 5 / 07$ & - & - & - \\
& & $11 / 20 / 07$ & - & - & - \\
PWS3 & 160 & $3 / 9 / 07$ & - & - & - \\
& & $4 / 5 / 07$ & - & - & - \\
& & $11 / 20 / 07$ & - & - & - \\
\hline
\end{tabular}

${ }^{a}$ Measurement not recorded. 


\section{Appendix B:}

Sample Documentation from Envirosystems, Inc. 
From: Charlie Hampp [mailto:hamppc@comcast.net]

Sent: Wednesday, January 16, 2008 3:08 PM

To: Alvarado, Jorge S.

Cc: Mohan Khare Ph. D.

Subject: Laboratory Error

I am sorry to inform you that the samples listed on the attached chain of custody have not been analyzed. The samples were logged into our LIMS system, but were not processed. The laboratory understands how much a problem the error represents and offers to analyze the original or replacement samples at no cost.

Please let me know what you would like us to do.

Regards,

Charlie Hampp

Director IT \& QAO

Envirosystems, Inc.

9200 Rumsey Road, Suite B102

Columbia, MD 21045-1934

410-964-0330 Ext. 225 410-740-9306 (fax)

hamppc@ comcast.net 


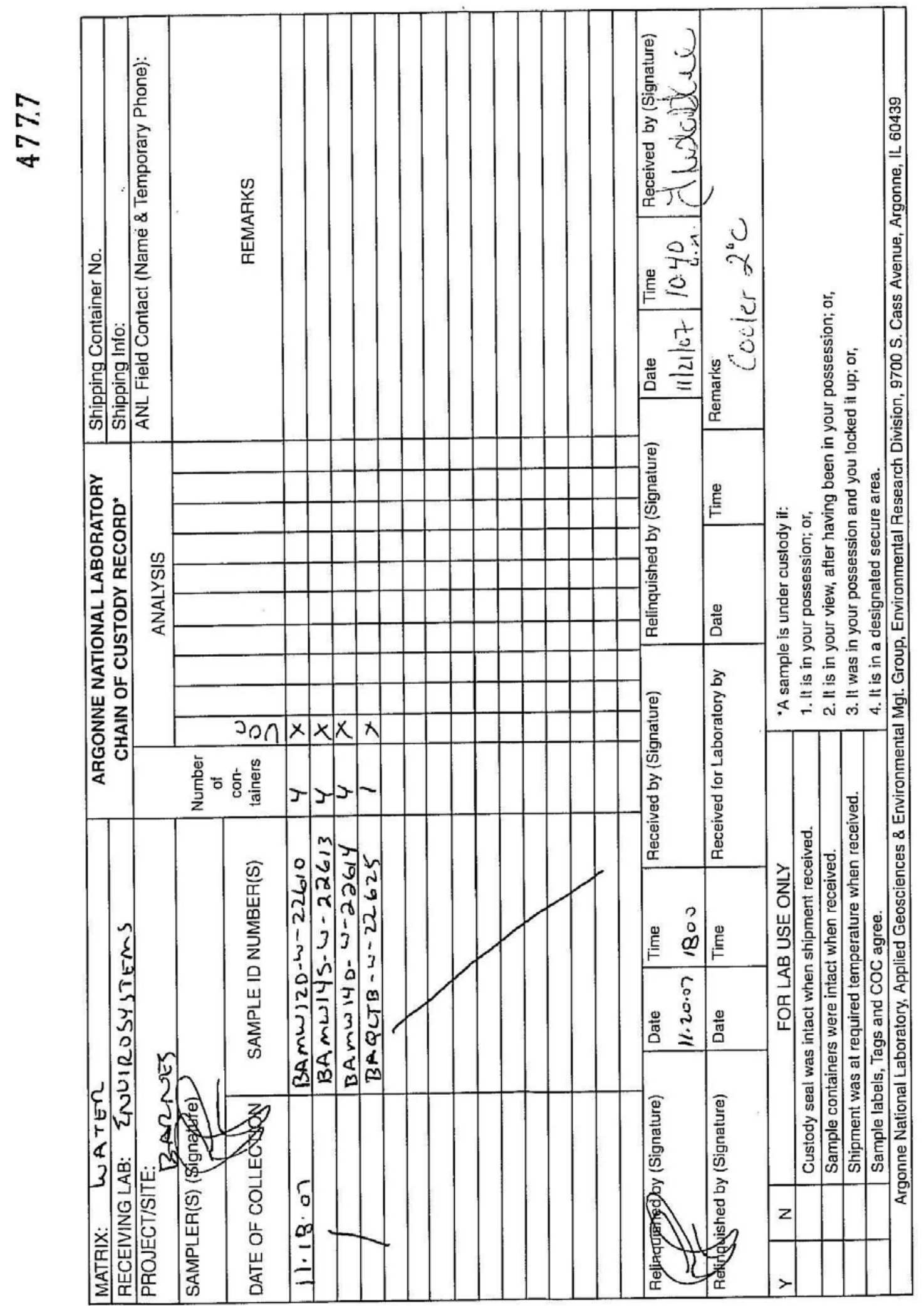




\section{Appendix C:}

Results from the AGEM Laboratory for Dual Analyses of Samples Collected at Barnes in November 2007 
TABLE C.1 Analytical results for samples and replicates collected at Barnes in November 2007.

\begin{tabular}{|c|c|c|c|c|c|c|c|c|c|}
\hline \multirow[b]{2}{*}{ Location } & \multirow[b]{2}{*}{$\begin{array}{l}\text { Screen } \\
\text { Interval } \\
\text { (ft BGL) }\end{array}$} & \multirow[b]{2}{*}{$\begin{array}{l}\text { Sampling } \\
\text { Date }\end{array}$} & \multirow[b]{2}{*}{ Sample } & \multirow[b]{2}{*}{$\begin{array}{l}\text { Sample } \\
\text { Type }\end{array}$} & \multirow[b]{2}{*}{$\begin{array}{c}\text { EPA } \\
\text { Analytical } \\
\text { Method }\end{array}$} & \multirow[b]{2}{*}{ Laboratory } & \multicolumn{3}{|c|}{ Concentration $(\mu \mathrm{g} / \mathrm{L})$} \\
\hline & & & & & & & $\begin{array}{c}\text { Carbon } \\
\text { Tetrachloride }\end{array}$ & Chloroform & $\begin{array}{l}\text { Methylene } \\
\text { Chloride }\end{array}$ \\
\hline \multirow[t]{2}{*}{ MW12D } & $115-125$ & $11 / 18 / 07$ & $\begin{array}{l}\text { BAMW12D-W-22610 } \\
\text { BAMW12D-W-22610FD }\end{array}$ & $\begin{array}{l}\text { Primary } \\
\text { Replicate }\end{array}$ & $\begin{array}{l}524.2 \\
524.2\end{array}$ & $\begin{array}{l}\text { AGEM } \\
\text { AGEM }\end{array}$ & $\begin{array}{l}1.6 \\
1.8\end{array}$ & $\begin{array}{l}N^{a} \\
N D\end{array}$ & $\begin{array}{l}\text { ND } \\
\text { ND }\end{array}$ \\
\hline & & & BAMW12D-W-22610 & Verification & SW8260 & $E S I C b$ & $N A^{c}$ & NA & NA \\
\hline \multirow[t]{3}{*}{ MW14D } & $123-133$ & $11 / 18 / 07$ & BAMW14D-W-22614 & Primary & 524.2 & AGEM & $0.6 \mathrm{~J}^{\mathrm{d}}$ & ND & ND \\
\hline & & & BAMW14D-W-22614FD & Replicate & 524.2 & AGEM & $0.4 \mathrm{~J}$ & ND & ND \\
\hline & & & BAMW14D-W-22614 & Verification & SW8260 & ESIC & NA & NA & NA \\
\hline \multirow[t]{3}{*}{ MW14S } & $108-118$ & $11 / 18 / 07$ & BAMW14S-W-22613 & Primary & 524.2 & AGEM & 1.2 & ND & ND \\
\hline & & & BAMW14S-W-22613FD & Replicate & 524.2 & AGEM & 1.2 & ND & ND \\
\hline & & & BAMW14S-W-22613 & Verification & SW8260 & ESIC & NA & NA & NA \\
\hline
\end{tabular}

a ND, not detected at an instrument detection limit of $0.1 \mu \mathrm{g} / \mathrm{L}$.

b ESIC, Envirosystems, Inc.

c NA, not analyzed.

d Qualifier J indicates an estimated concentration below the method quantitation limit of $1.0 \mu \mathrm{g} / \mathrm{L}$. 
Argonne

Environmental Science Division

Argonne National Laboratory

9700 South Cass Avenue, Bldg. 203

Argonne, IL 60439-4843

www.anl.gov

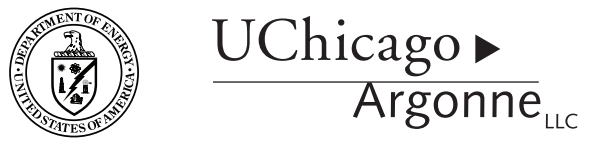

A U.S. Department of Energy laboratory

managed by UChicago Argonne, LLC 